\title{
Bir Taarruz, Üç Ricat: Sina-Filistin Cephesi Bozgunu ve Mustafa Kemal Paşa
}

\author{
One Attack, Three Retreat: Turkish Defeat on Sinai-Palestinian Frontline and \\ Mustafa Kemal Pascha
}

\author{
İsmail ÖZER*
}

\section{ÖZET}

1914-1918 y1lları arasında cereyan eden Birinci Dünya Savaşı Türk tarihi açısından önem arz ettiği kadar Ortadoğu tarihi açısından da önemli bir yere sahiptir. Osmanlı Devleti bu savaşta; Kafkasya, Irak, SinaFilistin, Hicaz-Yemen, Çanakkale, İran, Galiçya, Balkanlar gibi birçok farklı yerde savaşmış, bazılarında yenilmiş ve geri çekilmiş olmasına rağmen hiçbir yenilginin sonucu Sina-Filistin Cephesi gibi yıkıcı olmamıştır. Bu yenilgi Osmanlı Devleti'ni Mondros Mütarekesi'ni imzalamaya götüren sebeplerin en başında yer almıştır. Sina-Filistin Cephesi'nde Osmanlı orduları savaşın başından itibaren genel olarak bir çekilme eğiliminde olsalar da bu geri çekilme hiçbir zaman 1918 Eylülünde yaşanılan savaş sonrasında olduğu gibi bir bozgun seviyesine çıkmamıştır. 1918 Eylül ayında SinaFilistin Cephesi'nde yeni bir teşkilatlanmaya gidilerek IV. VII. ve VIII. Ordular Yildırım Ordular Gurubu adı altında Otto Liman von Sanders'in komutasına girmiştir. Cephenin sağında VIII. Ordu, solunda IV. Ordu merkezde ise VII. Ordu bulunmaktaydı. IV. Ordu Komutanı Cemal Paşa, VII. Ordu Komutanı Mustafa Kemal Paşa, VIII. Ordu Komutanı Cevat Paşa 19 Eylül 1918'de başlayan İngiliz taarruzu karşısında tutunamamış, VIII. Ordu tamamen dağılmış, VII. Ordu ise Şeria Doğusuna çekilmeye mecbur kalmıştır. Geri çekilme esnasında IV. Ordu da dağılmış ve nihayetinde VII.Ordu ancak Haleb'in kuzeyinde İngilizler'i durdurmayı başarmıştır.

Anahtar Kelimeler: Sina-Filistin Cephesi, Yıldırım Ordular Grubu, Mustafa Kemal Paşa, Edmund Allenby

\begin{abstract}
The First World War between 1914-1918 has an important place in the history of the Middle East as well as for Turkish History. In this war, the Ottoman Empire fought in many different places such as the Caucasus, Iraq, Sinai-Palestine, Hejaz-Yemen, Dardanelles, Iran, Galicia, the Balkans, although it was defeated and withdrawn in some, the result of no defeat was not as devastating as the Sinai-Palestinian Front. This defeat was one of the main reasons leading the Ottoman State to sign the Armistice of Mudros. Although the Ottoman Armies in the Sinai-Palestinian Front had a general tendency to withdraw from the beginning of the war, this withdrawal never reached the level of defeat as it was after the war in September 1918. In September 1918, a new organization was made on the Sinai-Palestine Front and IV. VII. and VIII. Armies came under the command of Otto Liman von Sanders under the name of Yildirım Armies Group. On the right side of the defense line was the VIIIth Army and on the left was the IVth Army center and the VIIth Army. IV. Army Commander Cemal Pasha, VII. Army Commander Mustafa Kemal Pasha, VIII. Army Commander Cevat Pasha withdrew against the British offensive. The 8th Army was completely dispersed and the 7th Army was forced to retreat to the East of the Jordan River. During the withdrawal, the 4th Army broke up and eventually the VII Army, but managed to stop the British in the north of Aleppo.
\end{abstract}

Keywords: Sinai-Palestinian Front, Y1ldırım Army Group, Mustafa Kemal Pasha, Edmund Allenby

\section{Giriş}

Birinci Dünya Savaşı'ndan önce Avrupa'da ittifaklar genişlemiş ve ortaya iki blok çıkmıştır. Almanya, Avusturya-Macaristan ve İtalya Üçlü İttifakı; İngiltere, Fransa ve Rusya Üçlü İtilâf'1

* Dr.Öğr. Üyesi, Ordu Üniversitesi FEF Tarih Bölümü, ismailozer@odu.edu.tr, ORCID 0000-0001-5910-4216 
oluşturmuşlardır. Daha sonra İtalya'nın İtilaf Devletleri'nin yanına geçmesi, Bulgaristan ve Osmanlı Devleti'nin de İttifak Devletleri safında savaşa katılmasıyla nihai güç dengesi kurulmuş olmaktaydı (Turan, 2015: 84). Bilindiği gibi I. Dünya Savaş1; Avusturya-Macaristan İmparatorluğu veliahdının Saraybosnada bir Sırp tarafindan öldürülmesiyle Avusturya-Macaristan İmparatorluğu ile Sirbistan savaşı olarak başlamış ve daha sonra her iki ülkenin müttefiklerinin katılımıyla umumi bir savaşa dönüşmüştü. Osmanlı Devleti, Avrupa'da başlayan savaşı kendi geleceğini tayin edici bir savaş olarak gördüğünden, buna bir var olma savaşı gözüyle bakmış ve Almanya ile kader birliği yaparak savaşa fiilen girmiş, Kafkasya, Irak, Sina-Filistin, Hicaz-Yemen, Çanakkale, İran, Galiçya, Balkan cephelerinde savaşmıştır ("Osmanlı Belgelerinde”, 2013: 3).

Türk cephelerinde 1917 yılı İngiliz ordularının ilerleyişi ile başlamıştır. 23 Şubat 1917'de Kutü'1 Amâre 11 Mart 1917 tarihi itibariyle de Bağdat İngiliz kuvvetlerinin eline geçmiştir. Bağdat'ın İngilizler tarafından işgal edilmesi Osmanlı Devleti için önemli bir milat olmuştur. Osmanlı Devleti, 1917 öncesinde iki tümen Galiçya'ya, üç tümen Romanya'ya ve iki tümen de Makedonya'ya göndermiş; seçme subay ve erlerden oluşan seçkin yedi Türk tümeni sınırları dışındaki cephelerde savaşmışlardır (Bayur, 1991: 369). Bu yardımlarından dolayı Enver Paşa da Bağdat'ın geri alınması için Türk ordusunu takviye edecek Alman kuvvetlerinin Türkiye'ye gönderilmesini talep etmiştir. Enver Paşa, 17 Mart 1917'de Almanya'ya giderek Alman Genel Kurmay Başkanlığ ile görüşmüş ve Balkan Cephelerinden geri çağrılacak olan Osmanlı birliklerinin yeni bir ordu teşkil edilmek üzere Halep’te toplanmasına karar verilmiştir. Buna göre II. III. ve V. Ordu'nun ihtiyat tümenleri ile Balkan cephelerinden gelecek bütün Türk tümenleri birleştirilerek VII.Ordu'nun kurulması kararlaştııılmıştır. Yıldırım Ordular Grubu (Heersgruppe F/Yıldırım) adını alacak olan bu ordu Alman Asya Kolu (Asien Korps) adı ile Alman askerlerinden oluşturulan kuvvet ve Avusturya Obüs Bataryaları tarafından desteklenecekti (Pomiankowski,1990:248). Yıldırım Orduları'nın başına da Prusya eski Harbiye Nazırlığı, Alman Genelkurmay Başkanlığı ve Romanya Ordu Komutanlığ görevlerinde bulunmuş olan Erich von Falkenhayn getirilmiştir (Bayur, 1956: 620).

VII. Ordu'yu takviye etmek amacı ile 48. Tümen (II.Ordu), Kafkas Süvari Tugayı (III.Ordu), 19 ve 20. Tümen(Galiçya), 5.Tümen (Makedonya), 24. Tümen ve 42. Tümen (Çanakkale), 59.Tümen (Aydın) Halep'e hareket ettiler (Sanders, 1998:219). Enver Paşa Filistin Cephesine giderek 24 Haziran 1917 tarihinde ordu komutanları ile Halep'te bir toplantı tertip etmiş, Irak ve Filistin Cepheleri için yeni yapılanmalara gidilmesi gerektiği kararlaştırılmıştır. Bu toplantılara VII. Ordu Komutanlığına tayin edilen Mustafa Kemal Paşa da katılmıştır. Yıldırım Ordular Grubu Komutanı Erich von Falkenhayn Süveyş ve Bağdat üzerine eşzamanlı bir Türk taarruzu yapılmasını gerektiğini ileri sürmüşse de Mustafa Kemal Paşa, Türk ordusunun mevcut durumunun ve kaynaklarının taarruza müsait olmadığını değerlendirmesini yapmıştır (Pomiankowski, 1990: 254). Mustafa Kemal Paşa ile Falkenhayn arasındaki anlaşmazlık Falkenhayn'ın Filistin Cephesi'nde Türk ordusunu Alman çıkarları için kullandığı düşüncesinde olması ve Araplar üzerinde Türklerin nüfuzunu yok etmeye dayalı Alman propagandası yapmasından kaynaklanmaktaydı. Mustafa Kemal Paşa'ya göre Almanların amacı Türk ordusunu kullanarak bölgeye daha fazla İngiliz askeri çekmek ve Araplar üzerinde hakimiyet kurmaktı (Çeliker, 1988: 169).

Mustafa Kemal Paşa, 20 ve 24 Eylül 1917'de Halep'te kaleme aldığı raporlarında komuta bölgesinde halk ile idare arasındaki tüm bağların kopmuş olduğunu adalet ve hukuka aykırı davranışların hükümete tepkiyi arttırdığını, savaş devam ederse karşında bulunulan en büyük tehlikenin her tarafta çürüyen Osmanlı hakimiyetinin bir anda çökme ihtimali olduğunu belirterek şu noktalara dikkat çekmiştir:

"Türk ordusu savaşın başlangıcına göre çok zayıftır. Birçok ordunun kuvveti, olması gerekenin 5/1'i kadardır. VII. Ordu'yu barış zamanında bile kuvvetli tutmak mümkün değildir. Ordu emrine gönderilen tümenin yarısı ayakta duramayacak kadar zayıf olduğundan ayıklanmış geriye 17-20 yaşındaki çocuklar ile 45-55 yaşındaki yaşlı askerler kalmıştır. İstanbul'dan gönderilen tümenler biner kişilik mevcutla hareket edip beş yüz kişilik mevcutla Halep'e gelmektedirler. Bütün bu durum karşısında yapılması gereken askeri savunma politikasi takip etmektir. Eldeki birlikleri, hatta tek bir askeri 
sonuna kadar saklamak gerekmektedir. Beslenmeyi sağlayıp yolsuzlukları en aşağı seviyeye indirerek memleketi lazım olduğu zaman çürük halde bulmamalıyı (Hatipoğlu, 2009: 23). Toplanabilecek tüm askeri kuvvetlerin acilen Sina Cephesine gönderilmesi gerekmektedir. Sina Cephesine bir grup ve iki ordu siğmaz. Düşman taarruz edince kuvvetlerin yalnız bir kumanda altında bulunmass zaruridir. Cepheyi tek bir komutan idaresine yani bana vermeniz yerindedir. Erich von Falkenhayn'a ne askeri ne de siyasi olarak güvenim olmadı̆̆ından emrinde çallşmak istemiyorum. Ĕger Sina Cephesi benim komutama verilmeyecekse VII. Ordu Komutanlığından affimı rica ederim"(Wallach, 1985: 199).

Türk ordusu'nun zayıf durumu, taarruz yapılması planlanan cephede coğrafi şartların zor olması ve Irak-Bağdat Taarruzu fikrinden haberdar olan İngiltere'nin Sina-Filistin Cephesi'nde taarruz hazırlıklarına başlaması üzerine Türkler Bağdat'ın alınması fikrinden vazgeçerek Sina-Filistin Cephesi'nin güçlendirilmesi yolunu seçmişlerdir (Çulcu, 2019: 187). Haddizatında Sina-Filistin Cephesi'nde İngilizlerin karşısında bulunan Mersinli Cemal Paşa'nın kumandasındaki IV. Türk ordusunun mevcudu İngilizlerin dörtte biri kadardı. VII. Ordu, Bağdat üzerine saldırdığında SinaFilistin Cephesi'nden bir İngiliz taarruzu gerçekleşirse VII. Ordu taarruzunu durdurmak zorunda kalacaktı (Emir, 2002: 41). IV.Ordu silah ve cephane yönünden olduğu gibi özellikle iaşe meselesinde oldukça sıkıntıdaydı. Cemal Paşa, Ağustos 1917 itibarı ile durumu şu şekilde özetlemiştir: "Askere günlük $350 \mathrm{gr}$ un ve hayvanlara da $2.5 \mathrm{~kg}$ yem verilebilmektedir. Sadece açllktan dolayı Temmuz ayında 20 bin asker hastalanmıştır" (Sedat, 2009: 56).

Yıldırım Ordular Grubu Komutanı Erich von Falkenhayn ile arasındaki anlaşmazlığın artması üzerine Mustafa Kemal Paşa, 2 Ekim 1917 tarihinde VII. Ordu Komutanlığı'ndan istifa ederek İstanbul'a gitmiş onun yerine ise Fevzi Paşa atanmıştır. Mustafa Kemal Paşa'nın İstanbul'da bulunduğu süreç içerisinde Filistin Cephesi'nde savaş Türk ordusu aleyhine cereyan etmiş ve önce stratejik Birüssebi ardından Gazze ve Kudüs İngilizlerin eline geçmiştir (Sedat, 2009:93-97). Bu başarısızlıklar üzerine 25 Şubat 1918 tarihinde Falkenhayn görevinden alınmış ve yerine Liman von Sanders atanmıştır. Mustafa Kemal Paşa da bizzat Sultan Vahdettin tarafından Fevzi Paşa'nın rahatsızlığından dolayı vekâleten Nihat Paşa'nın komuta ettiği VII. Ordu Komutanlığı'na 7 Ağustos 1917'de tekrar atanmıştır (ATASE ATA ZB 35-91). Mustafa Kemal Paşa, 28 Ağustos'ta Nablus'ta bulunan VII. Ordu karargâhı'na gelerek komutayı almıştır (Kinross, 2003:101). VII. Orduya bağlı 3.Kolordu (1,11.tümenler) Komutanlığı'nı Albay İsmet Bey, 20. Kolordu (26. ve 53. Tümen) Komutanlı̆̆ı'n1 Ali Fuat Paşa yapıyorlardı (Cemal, 2013:624).

Mustafa Kemal Paşa, Suriye'ye gelir gelmez süratle cepheleri dolaşmaya ve birlikleri teftiş etmeye başlamış, İngiliz cephesi karşısında Türk ordusunun muharip asker sayısının azlığından dolayı ordunun acilen takviyesini istemiştir (ATASE,ATA ZB 45-12aa). Mustafa Kemal Paşa görevi devraldığı zaman VII. Ordu emrindeki 3. ve 20. Kolordular Vadi al Far'a ile Şeria Vadisi arasındaki takriben $60 \mathrm{~km}$ 'lik bir cepheyi savunmaktaydı (ATASE, ATA ZB 45 12). Mustafa Kemal Paşa, 11 Eylül 1918' de yazdığı mektupta emrindeki orduların durumunu şu şekilde tasvir etmiştir: "Nablus'a geldim, Suriye'yi bir defa daha etüd ettim. Muharebe hatlarını baştanbaşa gezdim. Komutan, subay, erbaş ve erlerimizi gördüm. Ingiliz teşkilatı ve propagandası her yerde faaliyette, halk hükümetten nefret ediyor ve bir an önce Ingilizlerin gelmesini bekliyor. Düşman kuvvetleri ve vasitalar ile kuvvetli, biz ise onun karşısında pamuk ipliği”" (Bayur, 1990: 156). Örneğin Türk askeri kılığına giren İngiliz casusları etkisi ile VII. Orduya takviye olarak gelen 109. Alay 3. Tabur, Eylül ayında Afule istasyonunda Türk askeri kılığındaki İngiliz ajanlarının kışkırtması ile topluca firar etmiştir (Sanders, 1998: 59).

9 Eylül'de Kudüs'ü işgal ederek konumunu sağlamlaştıran İngiltere, Avrupa cephelerinde Almanlara karşı yürüttükleri savaşın seyrini değiştirmeyen kanlı siper savaşları yerine Osmanlı Devleti ve Bulgaristan'ı saf dışı bırakarak Almanya'yı ateşkese zorlamanın daha mantıklı olduğu kanaatine varmışlardır (Pomiankowski, 1990: 512). 1918 yılı Ocak ayında İngiliz Askeri Heyeti Filistin'e giderek yapılması planlanan genel taarruz için tetkiklerde bulunmuşlardır. Heyet, Irak ve Filistin cephelerinde aynı anda taarruz etmenin mümkün olamayacağını rapor edince Irak Cephesi'nde savunmada 
kalınarak Filistin Cephesi'nde taarruz kararı alınmış, Irak Cephesi'ndeki birlikler de peyderpey Filistin Cephesine nakledilmeye başlanılmıştır ("Birinci Dünya Harbinde", 1986: 516-517). Salahiye'de bulunan İngiliz askerleri Samarra'ya kaydırılırken yerine 6 uçak, 20 top ve 10 bin askeri ile Amerikan birlikleri yerleştirilmiştir (ATASE,4/11122, K.3705, D.34, F.8-2a).

Suriye-Filistin Cephesi hakkındaki literatüre katkı sağlayacağını düşündüğümüz çalışmada Mustafa Kemal Paşa'nı VII. Ordu Komutanlığı'na atanmasından Mondros Mütarekesi'ne kadarki süreç incelenmiş, VII. Ordu ve Mustafa Kemal Paşa'nın geri çekilmedeki rolü araştırılmıştır. Savaşların kazanılmasında sayısal, teknolojik ve lojistik üstünlügün zafer ve ricat arasındaki ince çizgiyi nasıl belirlediği vurgulanmaya gayret edilmiştir. Mustafa Kemal Paşa komutasındaki VII.Ordu'nun çöken bir cephede onları hızla takip eden İngiliz ve yavaşlatmaya çalışan Arap isyancıların arasından sıyrılıp Y1ldırım Ordular Grubu'ndan geriye kalan son kuvvetler olması gerçeğinden hareketle VII. Ordu'nun nasıl komuta edildiği hakkındaki tartışmalara açıklık getirilmeye çalışılmıştır.

\section{Eylül 1918 İngiliz Taarruzu ve Yıldırım Orduları Grubu}

İngiliz genel taarruzu öncesinde Yıldırım Ordular Grubunu teşkil eden üç ordunun durumları şu idi: Akdeniz kıyısından başlayıp 25km kadar doğuya giden bölgede VIII. Ordu (Cevat Paşa) emrinde 8 bin tüfek ve 132 top, VIII. Ordu'nun doğusundan Şeria Irmağına kadar VII. Ordu (Mustafa Kemal Paşa) emrinde 7800 tüfek ve 108 top, Şeria Irmağı'nın doğusundaki IV. Ordu (Mersinli Cemal Paşa) emrinde ise 12 bin tüfek, 104 top ve 2000 kılıç bulunmaktaydı. Ancak IV. Ordu'nun 5 bin kişilik bölümü Amman-Maan bölgesindeki demiryollarını Araplara karşı korumak zorunda olduklarından ana cephe hattında değillerdi (Bayur,1991: 452). Osmanlı Ordusunda görevli iken esir düşen veyahut firar eden Arap subayların birçoğu İngilizlerin safında çarpışmalara katılmışlardır. Özellikle Türk ordusunun ikmal noktaları, erzak ve cephane depoları ile demiryollarına yapılan saldırılar Türkleri cephe gerisinde asker bırakmaya mecbur etmiştir. Mekke Emiri Şerif Hüseyin'in oğlu Emir Faysal komutasındaki Arap ordusu bir İngiliz piyade ve bir istihkâm ile bir Fransız topçu bataryası ile destekleniyordu. Arap kuvvetleri 1918 yılında 8000 mevcutlu iki tümen 52 top ve 150 makinalı tüfek (Nedim, 1995: 124) ile keyfiyet değil ancak kemiyet olarak VII. Türk ordusu kadar bir askeri kuvvet haline gelmişlerdir.

Sina-Filistin Cephesi'ndeki İngiliz ordusu, Mısır Sefer Kuvvet Komutanı General Edmund Allenby komutasında 2 piyade kolordusu, Çöl Atlı Piyade Kolordusu, Fransız ve İtalyan müfrezeleriyle, ordu bağlı birliklerinden ve hava kuvvetlerinden oluşuyordu (Cemal, 2013:627). İngilizlerin 57 bin tüfek, 21 bin kılıç, 504 toptan oluşan ve lojistik destek hizmetleri neredeyse kusursuz işleyen bir ordusu yanında (Bayur, 1991: 452) Misır'da hazır olarak bekleyen 400 bin kişilik ihtiyat kuvveti de mevcuttu (ATASE,K.3718,D.38,F.1-24). Üstelik hava egemenliği kesin olarak İngilizler'de olup istedikleri yeri bombalama kabiliyetleri de vardı. İngilizler cephedeki askerlerini belli zaman dilimlerinde savaş dışı bölgelere çekip dinlendirme imkanına sahip oldukları için askerleri dinç ve moralli idi. Türk birliklerindeki askerler neredeyse savaşın başından beri ilk hatlarda çarpıştıklarından yorgun ve moralsizdiler. Üstelik geride yerlerini alabilecek ihtiyat kuvvetleri de yetersizdi. Haddizatında Liman von Sanders, İngilizlerin kıyı şeridinden değil de Şeria Nehri doğusundaki IV. Ordu Cephesi’ndeki Amman veya onun $30 \mathrm{~km}$ güneyindeki Medaba istikametinde saldıracaklarını düşündüğünden eldeki ihtiyatlar savaşın başlayacağı cephe hattının çok uzağında konuşlanmışlardı (Bayur, 1991: 452).

General Allenby, Türk ordusunu komuta eden Sanders'in beklediği gibi Doğu Şeria üzerinden taarruzu düşünmüyordu. Allenby bu istikamette Şam'a ilerlemenin zor olduğunu görmekteydi. Zira dağlık olan bu arazide ilerlemek hem çok güç hem de ilerleyen piyade ve süvariye topçu desteği vermek çok zordu. Bu sebeple sahil boyunca ilerlemenin daha kolay olacağı düşünüldü (Renouvin, 1982: 461).

VII. ve VIII. Türk ordusunun savunduğu cephe hattı coğrafi olarak İngilizlerin ağır topları ile tam kadrolu ve donanımlı süvari kolordularını rahatça kullanabilecekleri geniş bir muharebe alanına sahipti. Sayısal avantajları ile İngilizler geniş bir sahaya yayılarak savunma yapmak zorunda olan Türk birliklerine karşı belirlenecek herhangi bir noktaya ağırlık vermeleri halinde Türk hatlarını 
kolaylıkla yarabileceklerini düşünüyorlardı (Balcı, 2019: 69). İngiliz 21. Kolordusu bünyesindeki yedi piyade tümeninden beşi kıyıya yakın olarak düzenlendi. İngiliz Süvari Kolordusu da 21. Kolordu'nun solundan harekete geçecek ve kıyıda bekleyen savaş gemilerinin ateşinin de desteği ile hızla ilerleyebilecekti. Böylece Türk ordusunun geri çekilme istikameti olan kuzey ve kuzeydoğu kontrol altına alınarak VII. ve VIII. Ordu kuşatılarak imha edilebilecekti. Bu iki ordunun saf dışı kalması ile Amman'ın güney ve batısını savunan IV. Ordu da yalnız başına kalmış olacaktı (Erickson, 2009: 18). Dağınık ve küçük ihtiyatlar müstesna olmak üzere Şeria'nın batısındaki Türk kuvvetleri 70km uzunluk ve $20 \mathrm{~km}$ derinlikte bir dörtgen teşkil ediyordu. Bu dörtgenin kuzeyi Şeria Nehri üzerindeki Eddamiye'den başlayıp denize kadar uzanıyordu. Bu hat Nablus ve Tulkarimden geçiyordu. Türklerin Şam ile olan bütün irtibatı bu hattın doğu yarısının 25 mil kuzeyinde bulunan Afule istasyonu ile Beysan üzerinden icra ediliyordu. Filistin ve Hicaz demiryolu ise Dera'da birleşmekteydi. Afule, Beysan ve Dera'nın işgali Türk geri çekilme hattının kesilmesi demekti (Yılmaz, 2003: 79). İngilizler taarruz noktasını VIII. Ordu cephesi olarak belirleyince hazırlıklarını buna göre tamamlamışlardır.

General Allenby yapacakları genel taarruza hazırlık ve Türklerin savunma düzenlerini zayıflatmak amaciyla 16 Eylül 1918'de İngiliz-Arap kuvvetlerine IV. Ordu mintıkasında olan Dera'ya saldırmalarını emretmiştir. İngiliz-Arap kuvvetleri, Dera-Amman, Dera-Şam ve Dera-Affule arasındaki demiryollarını ve köprüleri tahrip ederek ulaşımı durdururken, İngiliz uçakları da Dera'yı bombalayarak Türkler için hayati öneme sahip bir demiryolu kavşağını kısmen kullanılamaz hale getirmişlerdir. Bu saldırılar karşısında Sanders, elindeki kısıtlı ihtiyat kuvvetlerini de asıl saldırı cephesi olacak VIII. Ordu bölgesinden çok uzağa yani Şeria'nın doğusuna göndermiştir. İngilizler 17 Eylül'de VII. Ordu savunması içerisinde yer alan Nablus'a saldırmışlar böylece asıl saldırıyı yapacakları VIII. Ordu bölgesini gizlemeye çalışmışlardır (Bayur,1991:454). Ancak 22. Kolordu (7,20.tümenler) Komutanı Albay Refet Bey, VIII. Ordu Komutanlığı'na İngiliz ordusundan firar eden Müslüman Hintli bir çavuşun İngilizlerin 19 Eylül sabahı Tulkarim ve Nablus istikametinde saldırıya geçeceklerini söylediğini rapor etmiştir (Yıldırım, 2009: 300).

Mustafa Kemal Paşa, 18 Eylül 1918 gecesi 3. Kolordu Komutanı Albay İsmet Bey ve 20. Kolordu Komutanı Ali Fuat Paşa'ya telefonla muhtemel bir saldırı karşısında teyakkuzda olmaları gerektiğini belirtip telefonu kapadıktan kısa süre sonra İngiliz topçu ateşi de başlamıştır (Tezer, 2009: 36). İngilizler Deyr ve Ebu Mağruk mıntıkalarında bulunan 3. Kolordu mevzilerine yoğun topçu ateşi gerçekleştirmişlerdir (ATASE ATA ZB 45 91ad). VII.Ordu da cephe hattındaki birliklere muharebeye hazır olmaları emri vermiştir (ATASE ATA ZB35-91ac). İngiliz topçu bataryaları ve donanması, VIII. Ordu karagahının bulunduğu Tulkarim ve Yıldırım Orduları karargâhı'nın bulunduğu Al-Nasira'yı yoğun ateş altına almışlar, İngiliz uçakları da bu ateşe destek vermişlerdir. Bu baraj ateşleri ile Tulkarim ve Al-Nasira arasındaki tüm haberleşme ve ulaşım bağlantıları kesilmiştir (Selek, 2006: 135). Bu ateşin şiddetini VII. Ordu 3. Kolordu 1. Tümen Komutanı Albay Hans Guhr şöyle tasvir etmiştir: "Sabaha karşı 4.00 sularında deniz ile demiryolu arasında ani bir baraj ateşi başladl. Şiddetli top ateşinden dolayı odamdaki pencereler şangırdlyor ve toprak zemin sarsilıyordu. Evimin düz damından batı ufkunda top namlulardan şimşek gibi çakan alevleri görüyor ve boğuk gümbürtü ile şiddetli yer sarsıntılarından İngilizlerin çok büyük çapll, uzun namlulu gemi toplarlyla ateş ettiği sonucunu çıkarıyorduk" (Guhr, 2016: 197).

Taarruz için VIII. Türk ordusu'nun karşısına beş piyade ve üç süvari tümeni, bir Fransız müfrezesi toplamıştı. Bu kuvvetlerden dört piyade ve üç süvari tümenini (Cemal,2013: 629) ilk mevzide karş1layacak olan 3 bin tüfek ve 94 topla kumluk arazideki mevzilerinde Albay Refet Bey'in 22. Türk Kolordusuna mensup askerleri olmuşlardır (Bayur,1991: 454). İngilizler 24 bin kişilik kuvvet ile 2 bin mevcutlu 22. Kolordu 20. Piyade Tümenine saldırmış kısa sürede galip gelmiş (Cemal, 2013: 628) son bir yıldır hastalık ve firarlar yüzünden güçsüz kalan 22. Kolordu kendinden çok kuvvetli İngilizler karşısında mukavemet edemeyerek (ATASE,1/1,K.222, D.342,F.7.) Kalansave üzerinden geri çekilmeye başlamıştır (ATASE,K.3718,D.38,F.1-24.) 20. Piyade Tümenine bağlı 62. ve 63. Alaylar arasında haberleşme kesilmiş, sağ cenah grubu'nda bulunan 7. Tümen Nehrülfalek gerisine çekilmiş, 20. Piyade Tümeni hattındaki Miskin İngilizlerin eline geçmiştir (ATASE,4/11122,K.3705,D.H-28,F.5-3). Böylece Yıldırım Ordular Grubu'nun sağ cenahına karşı yapılan İngiliz taarruzu neticesinde cephe kısa 
sürede yarılmış ve 22. Kolordu ise çoğu şehit olmak üzere dağılmıştır (ATASE A4/7302, K.3220, D.62, F.8).

VIII. Ordu Komutanı Cevat Paşa, taarruz sabahı Sanders'e gönderdiği raporunda sağ cenahının felç olduğunu 7. Tümen'in dağıldığı1, 19. Tümen'in Kefr Kasım bölgesine çekildiği ve 22. Kolordunun 94 topu dahil tüm ağırlıklarını kaybederek Et-Tire mevkiinde tutunmaya çalıştığını belirtmiştir (ATASE,4/11399,K.3787,D.37,F.1-14). Sanders, hatıralarında cephenin çöküşünü şu şekilde anlatmıştır:

\begin{abstract}
“Kıyı bölgesinin batı kesimindeki 7.Tümen ile ona bitişik 19.Tümene bağlı 57 ve 77.piyade alaylarının hızla ve tam olarak çökmelerinin nedeni, bugüne kadar anlaşılamamıştır. Bu birlikler, her ne kadar geniş bir bölge için çok zayıf iseler de, şimdiye kadarki çatışmalarda her zaman dayanmışlardı. Oysa bu kez, iki saatlik şiddetli topçu ateşinden sonra daha İngiliz piyade saldirıları başlamadan ortadan silinmişlerdi. Bu birliklerde artık savaşmak isteği kalmadiğı açıktı. Sonraki çekilişs sırasına da 7. ve 19. tümenlerden ne bir subay, ne de küçük bir parça görebildim”.
\end{abstract}

19. Türk Tümeni'nin açtığı boşluktan ilerleyen İngiliz süvari birlikleri ve zırhlı otomobiller sabah saat 10.00 'da demiryolunun doğusundaki Hableh ve Kalkiye mevzilerini de geçerek kuzeye doğru yönelmişlerdir. Kıyı bölgesinde hiçbir Türk direnişi kalmadığından bu cephe İngilizlerin ileri harekatına tamamen açık hale gelmiş, VIII. Ordudan geriye kalanlar ise Anabeta'ya kadar çekilmişlerdir. Sanders bundan sonraki gelişmeleri şu şekilde anlatmıştır:

\begin{abstract}
"19 Eylül öğleden sonra biz sanıyorduk ki, VIII. Ordu bir yandan geriye çekiliyor ve bir yandan da kendilerini izleyen düşman süvarisine karşı koyuyorlar. Yalnız bizimle bağlantı kuramıyorlar. Gerçekte ise durum şöyle imiş: Tulkarim'den Anabeta'ya giden yol Ingiliz uçaklar tarafindan atılan bomba ve makineli tüfeklerle öldürülen insan ölüleri, hayvan leşleri ve parçalanmış nakliye araçları ile tıkalı bir vaziyette imiş. Bu yoldan kaçmaya çalışan başıboş askerler bazı subayların ikazlarına rağmen aldırmadan kaçmaya devam etmişler. 19 Eylül günü ögleden sonraki saatlerde Mesudiye'den Cenin'e giden yol, VIII. Ordunun geri çekilen ağırlıklart ve kaçaklarla dolmuş" (Sanders, 1999: 72-76).
\end{abstract}

$\mathrm{Bu}$ kritik zamanlarda birlikler arasındaki haberleşme tamamen kopmuştur. Haberleşmenin kesilmesinde İngiliz topçu ateşinden ziyade Arapların yaptığı sabotajlar etkili olmuş hemen hemen tüm telefon ve telgraf hatları kesilmiştir (ATASE,A.1/1,K.222, D.342,F.7-2). Araplar, Dera demiryolu üzerinde de sabotajlar yaparak cephede açılan gediği kapatmak isteyen Türkleri felce uğratmışlardır(ATASE ATA ZB 35 91ab). Şam-Dera hattı'nın tahrip edilen yerleri tamir edilerek geçici bir süre ulaşıma açılsa da Dera-Amman hattı Araplar tarafindan 21 farklı noktadan güçlü patlayıcılarla havaya uçurulduğu için tamiri mümkün olmamıştır (ATASE,A.4/7302, K.3220,D.62,F.8). VIII. Ordu ile haberleşmenin kesilmesinin ardından VII. Ordu, Yıldırım Ordular karargâhı'na, VIII. Ordu cephesi’nin düşman tarafından yarıldığını ve İngiliz süvarilerinin hızlı bir şekilde kuzeye doğru ilerlediklerini bildirmiştir. VIII. Ordu Sol Cenahında bulunan Alman Asya Kolu Komutanı Albay Gustav von Oppen VIII. Ordu'yu kurtarmak amacı ile Tulkarim yönünde taarruza kalktı ise de başarılı olamayıp emrindeki kuvvetlerle kuzeye doğru çekilmeye başlamıştır (Nedim,1995: 148). VII. Ordu 3. Kolordu Komutanı Albay İsmet Bey yoğun topçu ateşine rağmen düşman taarruzuna karşı direndiklerini rapor etmiştir. Türk askerleri termometrenin 50 dereceyi gösterdiği kavurucu sicakta yemeksiz ve susuz olmasına rağmen kendisinden çok kalabalık ve güçlü İngilizlerin beş saldırısını püskürtmeyi başarmışlardır. Ancak daha fazla direnmeleri de mümkün gözükmemekteydi. Cephenin genelinde olduğu gibi kayıpları ağır, takviye ve cephane ikmali ise yoktu. 3. Kolordu birliklerinde sadece askerlerin kütüklüklerindeki cephane kalmıştı. Yaralılar için sağlık malzemesi ise hiç yoktu. En ağır zayiatı 200 şehit ile124. Piyade Alayı vermişti. 70. Piyade Alayında 160 ve 71. Piyade Alayında 90 şehit vardı (Guhr, 2016: 199). VII. Ordu 20. Kolordu Komutanı Ali Fuat Paşa, İngilizlerin 163. Alay ve Miralay Fahrettin Bey komutasındaki 26. Tümen cephesini yoğun ateş altına aldıklarını 163. Alay’a zehirli gaz mermileri ile saldırdıklarını top ateşinin ardından İngiliz piyadelerinin alaya saldırdıklarını bildirmiştir. Gece saat 3'ten sonra devam eden şiddetli çarpışmalarda İngilizler iki piyade tugayı ile 
saldırıp Türk mevzilerine girmişlerdir. 163. Alay Hırbet-Ruyet tepeler hattına çekilerek tekrar cephe almıştır. İngilizler saldırılarını 20. Kolordu üzerine yoğunlaştırdıklarından Mustafa Kemal Paşa 20. Kolorduyu güçlendirmek için Nablus'ta bulunan 13. Depo Alayını Mecdelli Beni Fazl'a, El Mağruk'ta bulunan 191. Alay 1. Taburu da Ayn-1 Fasay'a sevk etti. 109. Alay'ın 1 ve 3. Taburları da 20. Kolordu emrine verilmiştir (ATASE, ATA ZB 45 91ae).

VIII. Ordu Yıldırım Ordular Grubu'ndan destek kuvvet istemiş ve 19 Eylül gecesi sol kanadının Deir Istiya'ya alınacağını bildirmiştir (ATASE,5/7815,K.4523,H-19,F.1-40). İngiliz kuvvetleri kuzeydoğu istikametinde ilerlemeye başlayınca geri çekilme hatları kapanan VIII. Ordu düzensiz bir şekilde geri çekilmeye başladı. Özellikle İngiliz süvarileri geri çekilen Türk birliklerine büyük zaiyat verdirdiler (Nedim,1995:146). VIII. Ordu să̆ cenah grubu'nu tamamen kaybetmiş sol cenah grubu'ndan ise geriye sadece Alman Asya Kolu kalmıştır (ATASE,A.1/K.222,D.342,F.7-017). VIII. Ordu sol cenah grubu 20 Eylül gecesi Hableh-Deir Istiya hattına çekilmeye başlayınca VII. Ordu'nun sağ cenahı boş ve korumasız kalmaktaydı (ATASE,5/7815,K.4523, D.19,F.1-40). VIII. Ordu Komutanı Cevat Paşa, 20 Eylül gecesi saat 01.30 'da Mesudiye'deki karargâhı'ndan mevcut durumu şöyle rapor etmiştir: "Sağ cenah grubu bu gece Anabeta'nın kuzeyi ve Koze hattını tuttu. Sol cenah grubu geri çekilerek Beit Lid-Ferrata tepeleri hattını tutacakladır. Beit Lid her ne pahasına olursa olsun müdafaa edilecektir. Lüzumsuz araç gereç terk ve tahrip edilmektedir" (ATASE ATA ZB 45-12at).

İngiliz 20. Kolordusu'nun saldırısına uğrayan VII. Ordu merkezinin bulunduğu Nablus istikametinde İngilizler ilerlemekte zorlanmış olsa da VIII. Ordu'nun dağılması ve cepheyi yaran İngilizlerin VII. Ordu'yu kuşatma ihtimalleri üzerine Sanders'in de onayı ile VII. Ordu da 20 Eylül'de geri çekilmeye başlamıştır (Nedim,1995:148). İngiliz taarruzu devam ederken Sanders, bütün orduların bulundukları mevziyi korumalarını emreden şu tebliği yollamıştır: "VIII. Ordu sağ cenahını Kefr Haris-IskakaYatma-Qabalan-Elmugir -Hırbet-Ebu Zerka hattına çekilmelidir. Buna göre 3. Kolordu Kefr HarisIskaka-Yetma-Kobalan hattını 20. Kolordu ise Elmugir-Khirbet-Ebu Zerka hattını müdafaa edeceklerdir (ATASE, ATA ZB 35 91ag). Buna ek olarak 3. Kolordu ihtiyatında bulunan hücum taburu ile 109. Alay 1. Tabur Koze civarına nakl edilmişlerdir". Mustafa Kemal Paşa Liman Paşa'ya yazdı̆̆1 cevapta bu savunma hattının tutulmasında tamamen hemfikir olduğunu ifade etmiştir (ATASE, ATA ZB 35 91afa).

20 Eylül sabahı saat 5.30'da Yıldırım Ordular Grubu karargâhı'nın bulunduğu Al-Nasira kasabasının güneyindeki yol üzerinden İngiliz 13. Süvari Tugayı baskın yaparak karargâhı ele geçirmişler, Sanders son anda kaçmayı başarmış ve hatıratında bu olaydan şöyle bahsetmiştir: "Düşmanın içeriye kadar nasıl girdiği anlaşılamadı. Çünkü Depo Alayının güvenlikle görevli erleri bir daha geri dönemedi. Íngilizler, yerli Arapların kılavuzluğuyla patikalardan şehre girmişlerdi" (Sanders,1999: 78). İngiliz tugayı Al-Nasira' da birçok subay ile birlikte 2000 Türk askerini esir almış ve durmayarak önce El-Afule oradan da Cenin ve Beysan'a ulaşmıştır (Yılmaz, 2003: 89).

$\mathrm{Bu}$ hercümerç içerisinde Enver Paşa "Padişah Hazretleri kendilerine ve vazifeye karşl gösterilen bă̆lllık ve fedakarlı̆̆ mebni zatı alilerini fahri yaverleri arasına almayı ferman buyurmuşlardır" şeklinde bir telgraf çekerek Mustafa Kemal Paşa'yı tebrik etmiştir. Bu haber ve ulaştığı andaki tezat şu şekilde raporlara geçmiştir: "Herkes uykusuz ve 24 saattir hiçbirşey yememişs ne zaman yiyeceği de belli değildi. Gece yarısından sonra Başkumandanlık Erkanı Harbiye Riyasetinden birşeyler gelmişti. Lamba olmadı̆̆ için ay ışı̆̆ında okuduk. Kumandanımız fevkalade hüsn ve hizmet hidematına binaen Hazret-i Şehriyarlığına dahil edilmişti” (ATASE ATA ZB 45-12bd).

\section{Ordu Bakiyeleri ve VII. Ordu'nun Şeria Nehri'nin Doğusuna Geçişleri}

Yıldırım Ordular Grubu tarafindan VIII. Ordu sol cenah grubu ve VII. Ordu'ya Cenin-Al-Nasira ve Beysan üzerinden geri çekilmeleri emredilmiştir. IV. Ordu'ya da VII. Ordu'ya bağlı olarak geri çekilmesi ancak Maan tarafından yani Şeria Nehri'nin doğusundan gelebilecek düşmana karşı tertibat alınması emri verildi. Ancak İngiliz süvarileri 20 Eylül'de El Afule ve Cenin ve Beysan'ı işgal etmişlerdi (ATASE 4/7302, K.3220, D.62, F.8). 20 Eylül'de Nablusta bulunan Mustafa Kemal Paşa, 3. 
ve 20. Kolordulara İngiliz süvarilerinin VIII. Ordu'nun sağ sol ve gerisinde bulunduklarını söyleyerek şu emirleri vermiştir:

"VIII. ve VII. Ordular arasındaki hudut Ferata doğusu-Sevra doğusu-Beit Evde doğusuYasid doğusudur, 3. ve 20. Kolordular arasındaki hudut Gertyut doğusu-Agraba batıslBeit Hasan batısıdır. VII. Ordu Karargâhı Beit Hasan'da kurulacaktır (ATASE 4/11122,K.3705,D.28,F.7-1). VIII. Ordu Nablus istikametinden Tubas'a doğru geri çekilecektir. 3. Kolordu harekatını VIII. Ordu'ya göre düzenleyerek Telluza-Tammun hattına çekilcek. 20. Kolordu da Beit Dejan-Beysan yolu tarafina çekilecektir. Birinci derecede önemli olan husus Beysan havalisine ulaşmak olduğundan bu gidişi yavaşlatacak her şey imha edilmelidir (ATASE, ATA ZB 45-12bc). 3. Kolordu sağ cenahı ile VIII. Ordu kitalart ile ve 20. Kolordu sol cenahı ile IV. Ordu kitalart ile irtibatın muhafazasından mesuldür. 20. Kolordu Elmăgrık'tan kuzeybatıya giden Vadi al-Far'a 'yı muhafaza ile mükelleftir. VII. Ordu karargâhı Beit Hasan'da kurulacaktır" (ATASE, ATA ZB 45-12av).

VII. ve VIII. Ordu'nun geri çekilme hattında iki yol bulunmaktaydı. Birisi güneydoğu yönünde Eddamiye Köprüsü yolu, diğeri ise kuzeydoğu yönündeki Beysan'a kadar uzanan yoldu(Nedim,1995:150). VIII. Ordu geri çekilme hattı olan Nablus-Beysan yolunda ağır kayıplar vermiştir. VII. Ordu nispeten daha az kayıpla 20-21 Eylül günü Nablus'u boşaltarak kuzeye doğru çekilmesine devam etmiştir. Mustafa Kemal Paşa, Nablus'u boşaltırken sabah saat 2.15 civarında yazdığı raporunda durumu şu şekilde tasvir etmiştir: “Íngiliz Süvarisi Al-Nasira'yı almıştır. Ingiliz Süvarilerinin kuvvetinden dolayı teşebbüsatını daha cenuba doğru tevsi etmesi mümkündür. Bundan dolayı 3.ve 22. Kolordular geri yürüyüşlerini şimale karşı da temine mecburdurlar". VII. Ordu geri çekilmesini Beysan üzerinden planlarken VIII. Ordu'nun Beysan ve Al-Nasira'yı kaybetmesi hem kendinden arta kalanların hem de VII. Ordunun çekilme noktalarının kaybedilmesi demek olmaktaydı (ATASE, ATAZB 45-12a). 21 Eylül sabahı İngiliz uçakları Nablus'tan Tubas ve Beit Hasan istikametine hareket eden VIII. Ordu kaçkınları ve VII. Ordu birliklerini fark edip geçitlerin en dar yerlerini bombalayarak geri çekilmenin bozguna dönüşmesine sebep olmuşlardır ("Birinci Dünya Harbinde, 1986: 653) VII. Ordu 21 Eylül'de şiddetli taarruza maruz kalarak Dera istikametinde geri çekilmiştir (ATASE A4/7302,K.3220,D.62,F.8)

Enver Paşa, 21 Eylül'de Sanders'e gönderdiği telgrafta Dera-Taberiye'den Şam istikametine giden yolların muhafazası için Taberiye Gölünün doğusunda mevzi almanın ve mümkün mertebe DeraAfule tren hattının güneyinde kalarak İngilizler'e az toprak kaybetmek düşüncesinin yerinde bir tedbir olduğunu belirterek şöyle devam etmiştir: "Sahil ile Taberiye Gölü arasındaki mıntıkanın bilahare vaki olacak düşman süvarisinin bir ileri hareketine karşı setrü temin ve muhafazası için kuvvet müsait olsa IV. ve VII. Ordular kuva-yı külliyesinin Taberiye Gölü ăgzına sürülmesi pek şayanı arzu olurdu. Binaenaleyh să̆ cenahın emniyet ve muhafazasını mütemadi bir surette nazar-ı dikkatte bulundurmanız rica ederim. II.Ordu'ya mevcudundan ifraz edebileceği azami kuvvetle Yıldırım Grubu'na muavenet etmesini emrettiğim gibi 37. ve 47. Tümenlerin nakliyatının da hızlandırılması emredilmiştir "'(ATASE, A/1, K.222, D.342.F.7-20). 20 ve 21 Eylül 1918'de İngiliz uçaklarının makinalı tüfek ve bomba taarruzlarına rağmen 20. Kolordu muntazaman Koze'nin batı ve güneybatı sırtlarından, Vadi-i Samur'un kuzey sırtlarına Üm Hilal- Karn Sartabeh hattına çekilmiş ve dümdarları Kurin-Mjdlya-Beni Fadl hattında kalmıştır. 20. Kolordu Komutanı Ali Fuat Paşa, Beyt Fevrin doğusundaki Et Tuva tepesinden bağlı olduğu VII. Ordu'ya 21 Eylül sabahındaki durumu şu şekilde rapor etmiştir: "İki gün devam eden taarruzlart ile ziyadesiyle zaiyat veren düşman 20. Kolorduyu takip edememiş ve Calut-Birketül-Kahir-Douma hattının kuzeyine geçememiştir. Kolordu bugün tedrici surette Cebel-i Kebir-Ramallah yakınlarındaki Beyt Decan-Şeraf sirtlart Şeyh Kamil,Şunet, El Mesena-Reisül Hufuza hattına çekilmeye başlayacaktır. 3. Kolordu topçu kıtaatının Balat üzerinden Beit Hasan'a doğru çekilmekte olduklarl görülmüştür" (ATASE ATA ZB 45-12be). Kısa süre sonra 3.Kolordu'nun geri çekilen bütün topları İngiliz uçakları tarafindan bombalanmış, yolun tıkanması üzerine de bombardımandan kurtulabilen toplar İngilizlerin eline geçmesin diye Türkler tarafından ya patlatılmış ya da yolun kenarındaki derin vadilere atılmıştır (Guhr,2016: 202). 
Taberiye Gölünün güney ucunda önemli bir demiryolu kavşağında bulunan Samakh köyünde 120 Alman 80 Türk 8 makinalı tüfek ve 1 toptan oluşan Türk savunması 25 Eylül sabah saat 5.00'da saldıran İngiliz Süvari Tugayı ile birbuçuk saat çarpışarak eridi. Taberiye'yi savunan Binbaşı Schmidt'in müfrezesi de aynı gün İngilizler tarafından yenilerek geri atıldı (Guhr, 2016: 89). Samakh ve Taberiye'nin İngilizler tarafından işgali ve süvarileri ile kuzeye doğru ilerleyişi Taberiye-Dera mevzilerini muhafazayı imkansız hale getirmiştir (ATASE A4/7302,K.3220, D.62, F.8). Mustafa Kemal Paşa Nablus'un batısında VII. Ordu merkezinin gerisinde bulunan Beit Hasan mevkiinden 21 Eylül gece yarısı İstanbul'a şu raporu göndermiştir: “VII. Ordu'yu Vadi al Far'a kuzeyine çekmeye çalışlyorum. Yıldırım Orduları Grup Komutanlığı ile irtibat yoktur" (ATASE 4/11122,K.3705,D.28,F.13). Sanders de aynı gün Enver Paşa'ya çektiği telgrafta VIII. Ordu'nun sağ cenahının tamamen yok olduğu, sol cenahının ise çok azının kurtulabildiğini söylemiştir (ATASE A/1,K.222,D.342, F.7-17). Bu durum üzerine Enver Paşa, VIII. Ordu' dan geriye kalanların VII. Ordu'ya eklenerek yeni bir ordu meydana getirilebileceğini belirterek Hayfa'dan kuzeye giden yolların tutulmasını emretmiştir (Kocahanoğlu,2005: 36). Sanders ise VIII. Ordu'dan geriye kalan kıtalar ve VII. Ordu ile irtibatta olduğunu belirterek kendisine güvenilmesini istemiştir (ATASE A/1 K.222, D.342, F.7-14).

VII. Ordu'yu salimen geri çekebilme gayreti içerisinde olan Mustafa Kemal Paşa Beit Hasan'dan, IV. Ordu Kumandanı Mersinli Cemal Paşa'ya yazdığı telgrafta içinde bulunduğu durum ve kurtuluş yolunu şu şekilde belirtmiştir: "VII. Ordu'nun gerisinde bulunan ve İngilizler tarafindan işgal edilen Beysan'ın IV. Ordu tarafindan geri alınması Şeria Nehri batısındaki orduların kuşatmadan kurtarılmasında çok önemlidir" (ATASEATAZB-45-12bf). Mustafa Kemal Paşa'nın da ifade ettiği gibi İngiliz süvarilerinin Anabeta vadisinden ilerlemeleri Türkler için hayati bir tehlike ortaya çıkartmaktaydı (ATASE ATA ZB 35-91afa). Kuzey yönünde Beysan istikametinde çekilmesi gereken Türk orduları Anabeta vadisinden kuzeye ilerleyen İngilizler tarafindan engellenmekteydi. Bu durumda tek çare Şeria Nehrinin doğusuna geçmekti. Ancak Şeria Vadisinden doğuya çekilmek isteyen birlikler, , rrmaktan, sarp dağlık yollar ve derin vadilerden geçmek zorunda kalacaklardı. Topçu Bataryaları, erzak ve cephane kamyonları gibi vasıtaların bu yollarda ilerlemesi mümkün değildi. Bu yüzden Beysan'daki İngiliz varlığı VII. ve VIII. Ordu için hayati bir problem ortaya çıkarıyordu (Sedat, 2009: 202-203). Mustafa Kemal Paşa, 3. Kolordu Komutanı Albay İsmet Bey’e de 20. Kolordu'nun 21 Eylül gecesi Vadi al Far'a'nın kuzeyine geçmekte olduğunu 3. Kolordu'nun kuvvetlerini Nablus'un 20km kuzeydoğusunda Şeria Nehri batısındaki Tubas'ta toplayarak Beysan'a doğru gitmesi, Beysan hala İngiliz işgalinde ise de hemen Tubas'1n doğusundaki 20. Kolordu'ya iltihak etmesi gerektiği emretmiştir (ATASE, ATAZB 45-12bk).

Türk ordularının içerisinde bulunduğu kötü durum yani coğrafyaya hakim olamama, istihbarat eksikliği, ricat'ın getirdiği karmaşa büyük problemler ortaya çıkarmaktaydı. VIII. Ordu yaverlerinden Mülazım Cemal Efendi geriye doğru çekilirken VII. Ordu karargâhı'na gelerek düşman süvarilerinin Beit Hasan'a doğru ilerlediklerini kendisine ateş ettiklerini hatta karargâha 900 metre mesafede bulunduklarını bildirdi. VII. Ordu karargâh subayları 3. Kolordu'nun Ayn-1 Sıbyan civarındaki tepelerde olduğunu, bu görülen süvarilerin Alman Asya Kolu'na ait süvariler olması gerektiğini ifade ettiler. Durum Mustafa Kemal Paşa'ya da iletildi. Kısa bir süre sonra 3. Kolorduya mensup bir topçu subayı tarafından da mezkur haber doğrulanınca karargâh'ın ihtiyaten Vadi al Far'a kuzeyine (ATASE,ATA ZB 45-12bh) Cizyet'ül Ümmül Katr civarına taşınmasına karar verildi. Bu bölge Beysan ve Tubas'tan doğuya gelen yolların birleştiği yerdeydi. Bu nokta hem kolordularla irtibatı kolaylaştırılacak hem de dağınık haldeki birlikleri emir komuta altına alınması sağlanacaktı (Sedat, 2009: 245). Beit Hasan'dan geri çekiliş çok zor şartlarda cereyan etti. Raporlarda Türkler açısından çok elim hadiseler şöyle anlatılmıştır:

“VIII. Ordu'dan geriye kalan askerlerin Ingilizler geliyor diye çıkarttıkları şayia fena bir tesir icra etmiş ve o civarda bulunan VII. Ordu ağılıkları ile karargâh zabitan binekleri de bu tesiratla başlarını alarak cereyana kapılmış ve Vadi al Far'a şimaline giden asker kalabalığının arasına karışmıştır. Etrafinda kimse kalmadığını gören ordu karargâhı, Vadi al Far'a şimalinde ilerleyen bu akını durdurabilmek ve meseleyi tahkik 
etmek için Beit Hasan'ın şimalindeki sırtlara çıkmaya lüzum görmüştü. Saat 2.00'dan sonra kumandan ve maiyeti otomobillerle sirtlara doğru ilerlemiştir. Yol Ingiliz hava saldırıları ile tahrip edilmiş olan yük arabaları ve otomobillerle kapanmıştı. Nakledilmesi mümkün olmayan dosyalar her ihtimale karşı imha edildi. Kumandan ve Erkan-ı Harbiye Heyeti hayvanla yola devam etmekte ve tahrip edilmemiş ordu ağıllklarını sevk etmekte idi. Bu esnada altı İngiliz uçağ bomba ve makinalı tüfek ateşine başladl. Bu müthiş ateşin tesiratı ile yaralanan ölen insan ve hayvanlar çoğalmaya başlamış ve yolu büsbütün geçilmez bir hale koymuştu. Erkânı Harbiye heyeti yolu terk ederek sağdaki sirtlardan birisinin önünde kalmıştı. Etrafa yağmur gibi mermi düşüyordu. Bir süre sonra mukabelemizdeki sırtın eteğinden Beysan'a giden yolu takiben ilerleyen parekende efrad ve ağırlıklar göründü. Hemen bunları toparlamaya teşebbüs edildiyse de bunların kısmı ekserisi VIII. Ordunun bozgun askerleri olduğundan istifade edilemeyeceği anlaşılınca serbest birakıld $\imath$ (ATASE, ATA ZB 45-12bj).

General Allennby hatıratında Türk geri çekilmesinden şu şekilde bahsetmiştir:

“Ferve'den dokuz mil mesafede Ayn Şile mevkiinde kuzeye doğru Beysan'a bir yol ayrılır. Bu noktanın $1.5 \mathrm{~km}$ ötesinde Far'a Vadisi bir boğazdan geçer. Burada Türkler hava kuvvetlerimiz tarafindan şiddetle bombardıman edildi. Yük arabaları devrilince yol tamamen kapandl. Türkler Ayn Şilede istikametlerini değiştirerek Beysan'a yöneldiler. Bu esnada VII. Türk ordusu intizamın bütünüyle kaybederek Ferve-Beysan yolu ile Şeria Nehri arasındaki araziye dă̆lldı. Sabahleyin miktarları elli ile üç yüz arasında değişen Türk birlikleri teslim olmak için grup grup ellerinde beyaz bayraklarla Beysan'a geldiler. Beysan yolunda ricat eden Türkler tarafindan terkedilmiş 87 top ve 842 araba ele geçirildi".

22 Eylül tarihinde İngiliz süvarileri Nablus'tan Eddamiye köprüsüne giden yolları kontrol altına alınca Türk ordusunun geri çekilme hattını da kapatmış olmaktaydı (Yılmaz,2003:90-91). Kuzey yönünde Beysan istikametinde çekilmesi gereken Türk birlikleri Anebata Vadisinden kuzeye doğru ilerleyen İngiliz ordusunca engellenmekteydi. Şeria Vadisi'nin doğusuna geçmek için hareket eden Türkler ise geçilmesi güç dağlar ve derin vadiler içinde ilerlemek zorunda kalacaktı. Eddamiye Köprüsüne doğru çekilen Türk birlikleri İngiliz uçakları tarafından sabahtan hava kararıncaya kadar hiç durmadan bombalanmaktaydı. Çekilme yollarının tümü İngilizlerin elinde olduğundan dağınık Türk birlikleri birbirlerinden bağımsız Şeria'nın doğusuna doğru çekilmeye başladılar (Nedim, 1995: 152). Beysan'ın İngilizler'den geri alınması için VIII. Ordu'dan geriye kalan kuvvetlerle güçlendirilmeye çalışılan Alman Asya kolu görevlendirilmişse de (Yılmaz, 2003: 91) İngilizlerin açtığ1 yoğun top ve makineli tüfek ateşinden dolayı başarılı olamamışlardır (ATASEATAZB 45-12bm). İngiliz uçaklarının yoğun saldırısı altında Beit Hasan boğazından geçmeyi başarabilen VII. Ordu Tubas'tan doğuya doğru gelen yolların Beysan yolunu kestiği yerde toplandı. Keşif için Beit Hasan üzerinden Beysan'a gönderilen bir müfreze, makineli tüfek ve top ateşine maruz kalınca Mustafa Kemal Paşa, VII. Ordu'yu doğu ve kuzeydoğu istikametine yönlendirmişs (ATASE A1/1, K.222,D.342,F.7-16) Şeria nehrinin doğusuna geçmeyi denemeye mecbur kalmıştır. 22 Eylül 1918'de 3. ve 20. Kolordu komutanlıklarına da İngilizlerin Beysan'a hakim olduğunu kolorduların istedikleri zaman Şeria'nın doğusuna geçmekte serbest olduklarını yazmış ancak 3. Kolordu'ya ulaşılamamıştır (ATASE, ATAZB 45-12bn).

Şeria'nın batı kıyısındaki VII. Ordu'ya bağlı 20. Kolordu (26, 53. tümenler), Eddamiye yakınlarında birkaç saatlik çatışmadan sonra 22 Eylülde Şeria'y geçmiş ve kuzeydoğuya yönelmiştir (Sanders, 1999: 88). VII. Ordu 3. Kolordu 22 Eylül'de Tubas'a gelmiş, burada bulunan VIII. Ordu Komutanı Cevat Paşa, Mustafa Kemal Paşa'nın Şeria'nın doğusuna geçme emrini Albay İsmet Bey'e iletmiştir. 3. Kolordu Şeria'yı geçmek için Ebu Malih mıntıkasına gelmiş ancak 22 Eylül gecesi Ingilizler tarafindan tamamen kuşatılmıştır. Albay İsmet Bey teslim olalım teklifi getiren tümen ve alay komutanlarına red cevabı vererek kuşatmayı yarma kararı almış 1 ve 11. Tümenlere ayrı geçiş istikametleri vererek taarruza geçmiştir. Tümenler bir yandan savaşırken diğer yandan da sel yarıntılarından ilerleyerek geçiş noktalarına ulaşmaya çalışmışlardır. 1. Tümenin cephanesi tükenip ateşi azalınca bunu fark 
eden Ingilizler 71. Alayı esir almışlardır. Bu sırada Vadi al Far'a mevkiinde 20. Kolordu ile çarpışan Ingiliz süvarileri, 20. Kolordunun çekilmesi üzerine 3. Kolordu üzerine yönelerek 11. Tümeni kuşatarak ve 147. Alayı esir etmişlerdir. Buna rağmen 1. Ve 11. Tümenin kaçabilen kısımları yoğun düşman makinalı tüfek ve top ateşi altında Şeria Nehrini geçmeye başlamıştır. Bu sırada IV. Ordu 3. Süvari Tümenini geriye çekilmeye zorlayan Ingiliz ve Arap süvarileri boşluktan geçerek geçit yerlerinde karşıya geçmek için beklemekte olan 3.Kolordu'ya mensup askerleri şehit ve esir etmişlerdir. Böylece 3. Kolordu büyük bir zayiatla nehri geçmeyi başarmıştır. 11.Tümen Komutanı Albay Hans Guhr yaşananları şöyle tasvir etmiştir:

"Korkunç manzarayı hiç unutamayacağım. Kurşunlar ve düşen top mermileriyle kumlar havalanıyordu. Süvarisiz atlar, eşekler ve ürkmüş develer etrafta başıboş bir şekilde koşuşturup duruyorlar; onların arasında Türkler bir siper bulmak için can havliyle sağa sola koşuyor vurulup düşüyordu. Araplar, 70. ve 124. alaylar ile ağırlıkların geçişini zorlaştırmak için tam o sırada peyda oldu. Beyaz kefiyeli Arap süvariler Türklerin arasına daldılar. Kanlı, gögüus göğ̈̈se bir çarpışma oldu. Bedevi sürülerinin ardından çarpışmaya katılmak için Ingiliz süvarileri de geldi... Nehrin karşısında geçmek için çok kayıp vermiştik. Karşımda ölü gibi, sararmış benizli, yüksek ateşin pençesinde kıvranan, elbiseleri lime lime, ayaklarl yara içinde, büyük kısmı yalınayak, az sayıda Türk askeri duruyordu. Tümenin sadece 400 kadar tüfeği, 8 makineli tüfeği ve kullanılabilir vaziyette 4 dă̆ topu kalmıştı" (Guhr, 2016: 211).

3. Kolordu 24 Eylül gecesi Acluna ulaştı. Burada daha önce doğuya geçmiş olan 20. Kolordu ile birlikte 25 Eylül sabahı Evun'a buradan da Dera istikametine doğru geri çekilmeye devam ettiler (Sedat, 2009: 263-273). General Edmund Allenby hatıralarında Şeria Nehri kiyısında kistırdıkları bir Türk ordusundan şu şekilde bahsetmiştir: “Türkler Beysan'ın beş mil güneydoğusunda bulunan Meğaratu Ebu Naci'de Şeria Nehrinden geçmek için teşebbüs etmişlerse de 11. Süvari Tugayı tarafından önleri kesildi. Türklerin bir kısmı Şeria'nın doğu sahiline geçmişse de batı sahilinde kalan birlikleri üzerine hücum edilerek 25 makinal tüfekle birlikte teslim alındı" (Yllmaz, 2003: 91). General Allenby, isim ve birlik zikretmese de 22 Eylül'de gerçekleşen bu hadisedeki Türk birliklerinin VII. Ordu 3. Kolordu veya IV. Ordu Şeria Grubu'ndan Albay Esat Bey'in 24. Tümen'i olma ihtimali karşımıza çıkmaktadır.

IV. Ordu 3. Süvari Tümeni 22 Eylül öğleden sonra Beysan'a 20 km kala VII. Ordu ile karşılaştı. Mustafa Kemal Paşa, Beysan'ın durumunu IV. Ordu’ya bildirdiğini ancak cevap alamadı̆̆ını belirterek tümenin Taşköprü'ye kadar ilerlemesini ĕ̌er köprü işgal edilmişs ise güneyde uygun geçit yerleri aranmasını emretti ve süvari tümenini 300 mevcutlu iki piyade taburu ve bir subay ile takviye etti. Tümen keşif kolları yolları tarif etmek üzere yanlarına aldıkları kılavuz Araplar tarafindan aldatılıp Ingilizler tarafindan pusuya düşürülünce Beysan harekatı başarılı olamadı (Çulcu, 1993: 5658).VII. ve VIII. orduların mağlubiyeti üzerine ciddi bir saldirlya uğramayan IV. Ordu ise 23 Eylül'de Hicaz Demiryolu hattı boyunca düzensiz olarak geri çekilmeye başlamış Araplar ve İngiliz uçaklarının saldırıları sonrasında 2. Türk Kolordusu 5 bin askeri ile teslim olmuştur (Yılmaz, 2003: 94).

VII. Ordu 23 Eylül gece iki sularında Deyrul Ammar'ın iki km kuzeydoğusunda Şeria klyısına ulaşmış Ingiliz uçaklarının hedefi olmamak için gece karanlı̆̆ında karşı kıyıya geçilmesi kararı alınmıştır. Mustafa Kemal Paşa Şeria'nın doğusuna geçecek birliklerinin baskına uğramaması için Yarbay Hayri Bey Müfrezesini Beysan istikametinde emniyet tertibi almakla görevlendirdi (ATASE 4/11122,K.3705,D.28,F.7-6). Nehri geçmek için IV.Ordu 3.Süvari Tümeni güney-kuzey istikametinde 56km'lik bir yayı güvenceye alarak ordunun dümdarı vazifesi gördü (Çulcu,1993:55). Şeria Nehri'nin doğusuna geçiş şu şekilde gerçekleşmiştir:

"Toprak üzerine uzanarak bir süre istirahat etmeyi bile kar saylyorduk. Yine yiyecek bir şey bulamamıştık, sabaha karşı iki civarında rüzgardan zorla muhafaza edebildiğimiz mum ışı̆̆̆ında Mustafa Kemal Paşa harita üzerinde IV. Ordu 24. Tümen Süvari Bölüğünden Mülazım-ı Evvel Bedri Efendiden izahat alıyordu. Şimdi her iş bitmiş 
bulunduğumuz geçitten hemen mürura karar verilmişti. Suyun akarına geldiğimiz zaman herkes mataralarını doldurarak su içti. Çünkü uzun müddet susuzluktan bayılmıştık. Nehrin derinliğini anlamak için Bedri Efendi atıyla suya girdi ve geçidin Vadi-i Falik olduğu anlaşıldı" ("Birinci Dünya Savaşında, 1986: 668).

Mülazım-1 Evvel Bedri, yüzme bilen askerlerle birlikte nehrin iki tarafına ip bağlayıp geçişe hazır hale getirdi ve askerler geçtikten sonra en son Mustafa Kemal Paşa ve karargâhı da karşı kıyıya geçerek Aclun Dağları üzerinden Dera istikametinde ilerledi (ATASE ATA ZB 45-12bl). Geri çekilen Türk askerlerinin yara içindeki ayaklarından çölde idare eden ancak dağlık arazide işe yaramayan ince çarıklar parça parça dökülüyordu. Buna rağmen yürüyüşe devam etmek zorundaydılar zira geride kalan, kaybolan Türk askerleri ya susuzluktan ölüyor, ya vahşi hayvanlarca parçalanıyor bütün bunlardan kurtulabilirse de soyguncu Araplara av oluyordu(Guhr,2016:202). 25 Eylül'de Evun'a ulaşan Mustafa Kemal Paşa, 20. Kolordu'dan şu telgrafı almıştır: "20. Kolordu hafif ve ağır topçu bataryalart hariç diğer tüm kitalart ve 4 cebel bataryast ile 24 Eylül 1918 saat 14'te Aclun'a ulaşmıştır. Kolordu 25 Eylül'de Irbid istikametine geri çekilmeye devam edecektir" (ATASE4/11122, K.3705,D.28,F.18-2a). 26 Eylül'de VII. Ordu ve 20. Kolordu Dera' da birleşerek Dera-Muzayrib hattında toplanmıştır ("Birinci Dünya Harbinde, 1956: 684”). Mustafa Kemal Paşa, 3. Süvari Tümeni ve 24. Tümenin 26 Eylül'de Muzayribte toplanıp 3. Kolordu emrine verileceğini, Dera'daki Alman Asya Kolu'nun 20. Kolordu emrine verildiğini ve 20. Kolordunun da 26 Eylül akşamına kadar Dera'nın kuzeybatısında olmasını emretmiş kendisi de karargâhı ile Ar-Ramtha üzerinden Dera'ya hareket etmiştir (ATASE, 4/11122, K.3705,D.28.F.18-4). IV. Ordu 3.Süvari Tümen Komutan Vekili Vecihi Bey tarafından VII. Ordu'ya ulaşan raporda Arap çeteleri tarafından taarruza uğradıklarını söyleyerek durumlarını şu şekilde özetlemiştir: "Ekmek ve arpa bulamıyorum. Ne madeni ne de banknot beş para olmadığı için Araplar hiçbir şey göstermiyor. Parayı görürlerse gömdükleri yerden şüphesiz çıkarlyorlar. Mümkünse bir miktar para göndermenizi rica ederim" (Sedat, 2009: 278). 3. Süvari Tümeni 26 Eylül'de Aclun'a ulaştığında ambarlarda tonlarca arpa ve buğday ve depoda cephane vardı. Ancak menzil noktalarındaki hububat ve cephane demiryollarının Araplar tarafından sürekli sabotaja uğraması yüzünden açlık, susuzluk ve cephanesizlikten muzdarip Türk birliklerine ulaştırılamamıştır (Çulcu, 1993: 66-68).

VII. Ordu 23 Eylül'de 3000 kişiyle Dera'ya ulaşmıştır (ATASE A4/7302, K.3220, D.62, F.8). Dera'da bulunan Türk kuvvetleri Kefr (Kifl) Haris -Dera hattında savunma tedbirleri almıştı. Dera'nın 1.5km'lik yarıçapında yapılan tahkimat hattında 2000 asker bulunmaktaydı (Sedat, 2009: 281) 26 Eylül 1918'de IV, VII ve VIII. Ordu Komutanları Dera'da toplandılar. Bu toplantıda VIII. Ordu'nun elinde herhangi bir kuvvet kalmadığı için lağvedildi (Kocahanoğlu, 2005: 43-44). Mustafa Kemal Paşa geriye kalan kuvvetlerin tek bir komuta altında bulunmasını zira eldeki mevcudun iki ordu halinde bulunmaya yetmeyeceğini belirtmesine rağmen IV. Ordu Komutanı Mersinli Cemal Paşa tarafından bu teklif kabul edilmedi.

Mustafa Kemal Paşa, 3. Kolordu'nun Al Sheikh Maskin'e 20. Kolordu'nun Dera'nın 15 km kuzeydoğusundaki Khirbet Ghazaleh İstasyonuna gitmelerini, IV. Ordu'nun ise Dera-Muzayrib hattında kalarak VII. Ordu'nun Şam istikametindeki çekilişinin güvence altına alınmasını istedi (ATASE, A/4,11122, K.3707, D.35, F.13). Mustafa Kemal Paşa, 27 Eylül öğlen vaktine kadar Dera'da Yıldırım Ordular Grubu'ndan gelecek emirleri bekledi ise de herhangi bir emir gelmeyince hareket ederek Hizbetülezra'da mola verdi. Karargâh 27 Eylül gecesini Nemirülheva'da geçirdi. Geçilen köylerde sadece yaşlı erkeklerin olduğu görülerek gençlerin nerede oldukları sorulduğu zaman çalışmaya gitti cevabını alsalar da Türk subayları bu gençlerin isyancı Araplara katıldığını tahmin edebiliyorlardı. Arap çeteleri bulundukları ordulardan kopan, kaybolan birliklere hücum ediyorlardı(Sedat,2009:291). Birliklerinden ayrılan ve çevreye dağılan Türk erlerinden birçoğu, Şam'a doğru giden yollarda Arapların eline düşerek öldürülmüştür. Sanders hatıralarında bundan şu şekilde bahsetmiştir: "Bütün Arap halk silahlanmıştı. Subay ve erlere, küçük müfrezelere saldırlyor, baskınlar yapıyor, birçoğunu öldürüyor ve hatta parçalıyorlardı” (Sanders,1999: 86).

20. Kolordu, VII. Ordu ile birlikte hareket ettiği için Mustafa Kemal Paşa kolordu hareketlerini rahatça takip edebiliyordu. 3. Kolordu 26 Eylül gecesi Muzayribe gelmiş, istirahat edemeden yoluna 
devam ederek Al Sheikh Maskin'e ulaştıysa da burayı güvenli bulmayarak daha kuzeydeki Ümmütura civarına çekilmiştir. 3. Ordu'nun Araplar tarafından yollarda sık sık saldırıya uğraması üzerine Mustafa Kemal Paşa emrindeki birliklere Araplara karşı teyakkuzda bulunulmasını ve yürüyüş düzenine bilhassa önem verilmesini isteyerek Şam istikametine doğru gidilmesini emretmiştir (Sedat, 2009: 295). VII. Ordu 28/29 Eylül gecesi Mesmiye'ye 29 Eylül'de ise Kisve'ye çekilmiştir. Bu çekiliş sırasında İngilizlerden ziyade Arapların saldırılarına maruz kalınmakta idi. Araplar Türkleri mümkün olduğunca yavaşlatarak İngilizlerin Türklere yetişmesini sağlamaya çalışmaktaydılar. Yol güzergâhında bulunan kimi Arap köylerinde istihkâmlar dahi hazırlanmıştı. Örneğin VII. Ordu'nun yanını korumakla görevli 24. Süvari Tümeni Tafas köyü yakınlarından geçerken köyden üzerlerine ateş açılmıştır ("Birinci Dünya Harbinde,1986: 688”). 3. Kolordu 1. Tümen Komutanı Albay Hans Guhr, Araplar tarafından gerçekleştirilen saldırılardan birisini şöyle anlatmıştır:

\begin{abstract}
"Arapların asıl isyan bölgesinden geçiyorduk. Bundan böyle haydutça baskınlarını beklememiz gerekiyordu. Bu alçakların namussuzluklarını kısa süre sonra kendi gözlerimizle gördük: Tabanları yarılmış veya kulakları kesilmiş çırılçıplak Türk askerlerinin cesetleri yol kenarına dizilmişti, biraz ötede bacaklarındaki ă̆ır yaralara rağmen hala hayatta olan bir asker gördük, onun yanında ise dizkapakları kesilerek çıkarılmış bir Türk subayı yatıyordu" (Guhr, 2016: 215).
\end{abstract}

\title{
Şam ve Halep'in İngiliz İşgaline Uğraması
}

Türk ordusunun amacı Şam'ın güneyindeki Kisve hattında İngilizler'e karşı bir savunma hattı oluşturabilmekti (ATASE 4/11122,K.3705,D.28,F.20.) Ancak hat gerisindeki Arap saldırıları bu planı uygulama imkanı vermedi. Mustafa Kemal Paşa, 29 Eylül 1918'de Şam'a ulaşarak İstanbul'a durumu şu şekilde rapor etmiştir:

\begin{abstract}
“18/19 Eylül 1918'de başlayan muharebe neticesi VIII. Ordu'nun düştüğü kötü durum üzerine ricate mecbur olan VII. Ordu pek büyük bir tazyik altında Vadi al Far'a güneyine çekilmeye muvaffak olduğu sırada düşman Beysan'ı tutarak geri dönüş hattını kesmiş bulunuyordu. Bu engeli bertaraf etmek mümkün olamayınca orduyu batıya cephe aldırıp muharebe ile Şeria Vadisi'nin doğusuna geçirmeye çalışarak oradan da Cebel-i Aclun içinden kuzeydoğu'ya yönelerek Dera-Muzayrib hattını tutmaya muvaffak olunmuştur. Bundan sonraki kararım orduyu Kuneytra üzerinden Şam'ın güneyine çekmek ve DeraŞam istikametini IV. Ordu'ya terk etmek idi. Fakat Liman von Sanders'in talimat göndermemesi, Mersinli Cemal Paşa'nın da IV. ve VII. Orduların Şam'a gitmesine dair tebligatta bulunması sebebiyle ordumu Ingiliz Süvarileri ve Araplar ile muharebe ederek bugün Şam'ın güneyindeki Kisve’ye getirdim. Burada Liman Paşa'dan aldığım emir üzerine bu kuvvetleri Şam'ın muhafazası için Cemal Paşa'nın emrine verdim. Ingilizler bize kuvvet toplamak için firsat vermeden taarruzlarına devam ederlerse Şam'ın savunmasinı şüpheli görüyorum. Kuzeyden gelen kuvvetlerle bu kuvvetlerin emniyetle yetişebilecekleri Rayak'in kuzeyinde esaslı bir savunma hattı tutmak ve Beyrut-ŞamRayak hattının güneyinde mevcut kuvvetler ile bir perde hattı ile yetinmenin münasip olacağı düşüncesindeyim ”(ATASE,A.1-1,K.222,D.342,F.7-117).
\end{abstract}

Liman von Sanders 29 Eylül günü verdiği emirle VII. Ordu ile VIII. Ordunun Şam’a doğru çekilmekte olan kalıntılarının toplanmasıyla oluşturulacak birliklerden kurulacak Rayak Cephesine Mustafa Kemal Paşa'yı atarken Şam'ı savunma görevini de VII. Ordu birlikleri ile takviye edilen IV.Ordu'ya tevdi etmiştir (Sanders, 1999: 95). Mustafa Kemal Paşa Şam'ın savunulmasının zor olduğunu eğer savunmada ısrar edilirse bahçeler arasında sıkışacak olan Türk toplarının etkin şekilde kullanılamayacağını ifade ederek (Yıldırım, 2009 :233) daha esaslı tedbir olarak savunma hattının Rayak'ın kuzeyinde olmasını istemiş ancak fikirleri kabul görmemiştir (ATASE, A.1-1, K.222, D.342, F1-118). Yıldırım Ordular Grubu'nun emri üzerine Mustafa Kemal Paşa, VIII. Ordu 125. Alay ve 3. Süvari Tümeninin Rayak'a hareketini emretmiştir (ATASE,4/11122,K.3705, D.28,F.20-1). Şam 
Savunmasında çarpışmalar 30 Eylül sabahından akşama kadar devam etmiştir. İngilizler Şam’ın güney ve güneybatısından piyade, süvari, top ve zırhlı otomobillerle saldırmışlardır. Düşmanın ana saldırı merkezi Şam'1n güneybatısı olmuştur (ATASE,A.1-1,K.222,D.342,F.7-123). Sanders'in Şam savunması ile ilgili stratejik bir göreve Arap Milliyetçisi Ali Rıza Paşa el-Rikâbi adında emekli bir asker ile 8. Kolordu Komutanlığı yapmış yine Arap asıllı Yasin Hilmi Paşa'yı ataması Şam'ın kısa zamanda düşmesinde en büyük etken olmuşlardır (Yıldırım, 2009: 300). Bu zatlar hem savunmanın iç bölgelerde yapılması noktasında 1srar ettikleri gibi hem de İngilizler Şam'a yaklaşır yaklaşmaz onlara iltica etmişlerdir. Nitekim Yasin Hilmi, Şerif Faysal'ın Arap ordusu'nda kurmay başkanı olmuştur (Bayur, 1991: 459).

Mustafa Kemal Paşa 29 Eylül gecesi Şam'dan hareket ederek 30 Eylül'de Rayak'a ulaştığında Şam'ın düştüğü haberini almış Berede Vadisi yoluyla Şam'dan çekilebilen askerlerin dağınık bir şekilde geldiği Rayak'ta bu askerleri durdurup toparlamaya gayret etmiştir (Nedim, 1995: 155). VII. Ordu emrine verilen 43. Tümen Rayak-Beyrut yolunu tutarken, Alman Asya Kolu Taanayel'de tertibat almıştır (Sedat, 2009: 352). Mustafa Kemal Paşa kısa zamanda Rayak’ı savunmanın çok güç olduğunu görmüştü. Alman Asya Kolu'nun elinde yeterli asker olmadığı gibi eldeki yegâne kuvvet olan ve bugüne kadar hiç savaşa girmemiş II. Orduya bağlı 43. Tümen Arap askerlerinden meydana geldiğinden düşman karşısında ne tutum takınacakları belirsizdi. Örneğin, 43. Tümen'den Taanayel mıntıkasına takviye için gönderilen birlikler 1 Ekim'de subayları ile birlikte topluca firar etmişlerdir ("Birinci Dünya Harbinde, 1986:705”).

Mustafa Kemal Paşa Şam'ın esnek bir savunma planı olmadığı için sonucun Türkler için mağlubiyet olacağını daha önceden belirtmişti. Rayak civarında yeniden oluşturulan savunmanın da aynı akıbet ile karşı karşıya kalmasını engellemek için Baalbek civarında oluşturulacak mevzilerin gerisinde toplanma kararını aldı (Sedat, 2009: 361). Mustafa Kemal Paşa Baalbek'e giderek burada savunulması kolay bir mevzi seçmeye karar vermiş ve Yarbay Mümtaz müfrezesini de Rayak-Baalbek yolundan geçen bütün askerleri 20. Kolordu emrine alarak mevziyi korumakla görevlendirerek şu emirleri vermiştir:

"2 Menzil Taburu, 3 Bölük, 1 jandarma Taburu, 19 makineli tüfek, 264. Batarya, $105 \mathrm{~mm}$ 'lik iki top, Baalbek'te 20. Kolordu Komutanı emrinde görev yapacaklardır (ATASE, 4/11122, K.3707, D.35, F.17). Alman Asya Kolu düşmanla temas halinde ciddi bir muharebeyi kabul etmeksizin Baalbek'e çekilerek 20. Kolordu emrine girecektir. 3. Kolordu Komutanı Albay İsmet Bey rastladı̆̆g bütün başıboş birlikleri emri altına alarak Rayak'a doğru gelecek, bu mümkün olamaz ise Al Nabk-Humus istikametinde çekilerek orada ordu emirlerini bekleyecektir. Rayak istasyonunda bulunan cephane Humus'a taşınacak, taşınması mümkün olmayan her türlü malzeme imha edilecek”.

Sanders ise bu düzenlemeleri kabul etmeyerek emrettiği gibi Rayak'ta toplanılmasını isteyince Mustafa Kemal Paşa kendisine verilen emirleri yerine getireceğini ancak panik halinde geri çekilen birliklerin durdurularak düzenlenip tekrar muharebe hattına sokulması için düşman temasından uzaklaşılması lazım geldiğini söylemiştir (ATASE, 4/11122, K.3705, D.28, F.22-2). Mustafa Kemal Paşa 1 Ekim'de İngilizlerin Beyrut'u işgal ettikleri haberini almıştır.1 Ekim günü Albay von Oppen'in Asya Kolu'nun Taanayeldeki karargâhı'nda IV. Ordu komutanı Mersinli Cemal Paşa, VII. Ordu Komutanı Mustafa Kemal Paşa ve Yıldırım Ordular Grubu Komutanı Liman Von Sanders buluşmuşlar ve Sanders, IV. ve VII. Ordulara Humus'a doğru çekilme emrini vermiştir. Yeni planlamaya göre Cemal Paşa, Humus'ta komutayı ele alacaktı ve bu amaçla kurmay heyetiyle birlikte hemen oraya hareket edecek, oraya gelen kuvvetleri toplayıp düzenli birlikler durumuna sokacaktı. Mustafa Kemal Paşa Rayak'ta kalmaya devam ederek, güneyden gelen döküntüleri toplayacak ve sonra bunları Humus'a getirmeye çalışacaktı (Sanders, 1999: 100).

VII.Ordu'nun düşmanla bir teması yoktu. İngilizler Rayak ve civarında topyekûn bir taarruz hareketinde bulunmuyor uçakları ile zaman zaman saldırıda bulunuyordu (ATASE, A4/10481,K.3642,D.177,F.4)i Liman von Sanders, İngiliz zırhlı otomobillerine karş1 Mustafa Kemal Paşa' dan geniş hendekler kazılarak tertibat aldırmasını emretmiştir (ATASE,A4/11122, K.3705,D.29,F.32- 
4). Rayak'taki görevlerini tamamlayan Mustafa Kemal Paşa 2 Ekim gecesi askerlere istirahat verirken düşman uçaklarına hedef olacak ve ordunun ilerleyişini yavaşlatacak ağırlıkları geceden Baalbek üzerinden Humus'a göndermiştir (Yıldırım, 2004: 309). Rayak İstasyonundaki su depoları, demiryolu makasları, geriye gönderilme vasıtası olmayan tahıl, giysi ve cephane depoları havaya uçurulduktan sonra son tren sabah saat 6'da Rayak'tan hareket etmiştir (Sanders, 1999: 101). Humus'ta Mustafa Kemal Paşa ile Liman von Sanders arasında yapılan toplantıda VII.Ordu'nun Halep'in güneyine konuşlanması, 3 ve 20. kolorduların da bu mıntıkaya gelmesi kararlaştırılmıştır (ATASE,4/1993,K.2697,D.113,F.38-5). VII. Ordu'ya bağlı olup birliklerinden kopup Humus'a gelen askerler de trenle Halep'e yollanarak VII. Ordu emrine gönderilmekteydi. Baalbek'e çekilen Albay von Oppen'e de Alman Asya Kolundan kalan birlikleri alıp Halep'in kuzeyine gelmesi emredilmiştir (Sanders, 1999: 102) VII. Ordu karargâhı 4 Ekimde Humus'tan ayrılarak 5 Ekim sabahında Halep'e ulaşıp Baron Otelini karargâhı yapmıştır (Kemal, 2013: 52). Mustafa Kemal Paşa, 3. Kolordu Komutanı Albay İsmet Bey geri çekilme sırasında hastalandığından onu İstanbul'a göndermiştir (Yıldırım,2004:300). Mustafa Kemal Paşa VII. Ordu Şam'dan ayrılırken Şam'ın savunması için IV. Ordu'ya takviye birlikleri bırakmıştı. Ancak Şam'ın düşmesi ile bunlar da Şam'ı savunan IV. Ordu ile birlikte şehit veya esir düştüklerinden VII. Ordu emrinde az sayıda kuvvet kalmıştı. Mustafa Kemal Paşa bu sebeple Halep'ten emrindeki birliklere şu emirleri yayınlamıştır:

"VII. Ordu emrinde bulunan von Oppen grubu ve güney istikametinden hangi orduya mensup olursa olsun gelen dağınık birlikler, nakliye vasıtalart ve malzeme Khan TumanAl Vadihi (Vuzuhi) hattında durdurulup toparlanarak düzeleceklerdir. Güneyden yürüyerek veya trenle gelecek bütün dağınık Türk birlikleri Khan Tuman ve Al Vadihi Istasyonlarının kuzeyine geçirilmeyecektir. Türk teşkilatının Khan Tuman hariç Al Vadihi İstasyonu hattında ve Alman teşkilatının Khan Tuman dahil batıda tertip edilecek ordugahlarda düzenlenmesi uygun olur. Piyade kıtaları 150'şer mevcutlu üçer bölükten, mekkarecisi ve tabur subaylart ile beraber toplam 500 asker ve 50 hayvan mevcudunda taburlar teşkil edilecektir. Bunlara birden itibaren numara verilmelidir. Makineli tüfek bölükleri ellişer nefer üzerinden tertip edilmelidir. Topçu ve diğer sinıflardan piyadeye hizmete elverişli olanlar piyade sinıfina verilmelidir. Nakliye vasıtaları ile gelen askerlerin büyük kısmı cephede hizmete elverişlidir. Bunların zaylf askerler ile değiştirilmesi, ă̆ırlıkları ile birlikte sürüklenip gelen askerlerin birlikler içine derhal alınması gerekmektedir" (ATASE, 4/11122, K.3705, D.28, F.25-8).

Liman von Sanders, 6 Ekim 1918'de Halep'e gelerek II. Ordu Komutanı Nihat Paşa ve VII. Ordu Komutanı Mustafa Kemal Paşa ile toplantı yapmıştır. Kıyıda Arap isyanının gelişmesinin engellenmesi, VII.Ordu'nun Anadolu ile bağlantısının kesilmemesi ve İskenderun Limanına yönelik olası bir İngiliz çıkarması ihtimaline karşılık Nihat Paşa ve karargâhı 10 Ekim 1918'de Adana'ya ulaşmıştır (ATASE, A4/11122, K.3707,D.42,F.4).

İngilizler Kevkeb istasyonunu işgal ederek iki zırhlı otomobil ve iki süvari takımı ile 8 Ekim' de Hama yakınlarındaki Kumhane İstasyonuna gelmişler buradan da Hanyanun'a geçmişlerdir (ATASE 4/11122,K.3705,D.29, F.29). Enver Paşa, dağılan ve çok zayiat veren IV. Ordu'yu 13 Ekim 1918'de lağvederek (ATASE, A4/11122, K.3705, D.28, F.44) IV. Ordu Komutanlığı emri altında bulunan bütün birlikleri de VII. Ordu emrine vermiştir. 3. Süvari Tümeni karargâhı 11. Tümen karargâhı'nı takviye etmiş, 47. Tümen ve IV. Ordu Makineli Tüfek Mektebi 1. Tümeni, depo alayı ve IV. Ordu' dan geriye kalan tüm bölükler 24. Tümene dahil olmuşlardır (ATASE, A4/11122,K.3707,D.42,F.4). Mustafa Kemal Paşa IV. Ordu'dan geriye kalanların kendisine verilmesi ile yeni bir teşkilatlanma yapmış VII. Orduyu 1, 11, 24 ve 43. Tümenlerden yeniden kurmuştur.17 Ekim 1918'de Halep'in güneyindeki köylerde bulunan ve her birinde 5 bin asker bulunan 1 ve 11. Tümenlerden Ali Fuat Paşa komutasındaki 20. Kolordu'yu, 24 ve 43. Tümenlerden ise Albay Selahattin Bey komutasındaki 3. Kolorduyu oluşturmuştur (ATASE,4/11122,K.3705,D.29,F.8-1). Yeni tertiplenmeye göre 20. Kolordu Halep çevresine yayılarak aynı zamanda Halep-Hama demiryolunu Arap saldırılarına karşı korumakla görevliydi (ATASE,4/11122,K.3705,D.29,F.13-1). 
3.Kolordu'ya bağl1 24.Tümen Halebin kuzeyindeki Katma istasyonuna (Sanders, 1999: 371), 43.Tümen ise Muslimiye'de mevzilenmiştir (ATASE, 4/11122, K.3705, D.29, F.31-4). Halep hattının savunulmas1 amacıyla güneyde oluşturulan istihkamlar da Hama-Khan Tuman arasında yer almaktaydı (ATASE, 4/11122,K.3705,D.29,F.13-2). Yeniden teşkil edilen VII. Ordu, çoğunluk olarak bozgunu yaşamış kaçak ve perakende erlerden oluşturulmuştu. Manen ve maddeten sarılmış olan bu birliklerin başına geçirilen birçok subay da erlerden farklı değildi. Savaşlarda pişmiş kudretli subayların büyük kısmı esir veyahut şehit düşmüşlerdi. Topçu kuvveti yok denecek kadar az olan bu ordu disiplin, kuvvet, teşkilat ve nakil kabiliyeti bakımından düşmanla meydan savaşı yapabilecek kabiliyette değildi. Halep ve çevresindeki arazi taarruza elverişli savunma yapmak için ise yetersizdi. Katma civarından itibaren kuzey ve kuzeydoğuya doğru savunmaya elverişli bazı yerler olsa da ancak İslahiye ve kuzeyindeki arazi bir dereceye kadar savunmaya elverişli görünmekteydi (ATASE, 4/11122,K.3705,D.29,F.8-1).

İngilizler tüm kuvvetlerini Humus civarında toplayarak yığınak yapmaktaydılar. Hama civarında İngiliz işbirlikçisi Arap kuvvetleri toplanmış, Um El Recim İstasyonuna saldırarak buradaki Türk askerlerini şehit edip istasyonu yağmalamışlardır. Halebin $45 \mathrm{~km}$ güneyinde $\mathrm{Abu}$ al-Duhur civarında 1000 kişilik bir Arap kuvveti de Türk nakliye trenlerine saldırmışlardır. İngiliz Savaş gemileri İskenderun-Arsuz limanını bombalamış, Lazkiye İngilizler tarafından işgal edilmiştir (ATASE,4/11122,k.3705, D.29, F.13-2).

İngilizlerin birlikleri, Hama ve Humus'a doğru ilerlemeleri üzerine Mustafa Kemal Paşa, Hama'y1 boşaltarak(Sanders,1999:106) kuvvetlerini kuzeye Hemdaniye İstasyonu civarına çekti. İngilizler ve Araplar 16 Ekimde Hama'ya girdiler (ATASE,4/11122,K.3705, D.29,F.13-2). İngilizler bir süvari iki piyade tümeni ve yol boyunca kendilerine katılan kalabalık Arap aşiretleri ile 17 Ekim'de Humus'u işgal etmişlerdir (ATASE,4/10481,K.3642, D.177,F.89.23). 23 Ekim günü Hansebil, İngilizlerin ve Arapların saldırısına uğradı. Bu sırada Halep istasyonu da havadan sık sık bombalanıyordu (Sanders, 1999: 107).

23 Ekim 1918'de saldırıya geçen İngilizler ve beraberlerindeki Arap kuvvetleri Halep'in güneyine kadar ilerlemişlerdir. 23 Ekim tarihinde elinde beyaz bayrak taşıyan İngiliz Yüzbaşı Macintyre 1. Tümen emniyet hattına kadar gelerek General H. J. Macandrew'in Halep'in teslim edilmesini isteyen mektubunu getirdiyse de Mustafa Kemal Paşa tarafindan görüşmeye değer bulunmadığından İngiliz Yüzbaşı geri gönderilmiştir (ATASE,4/10481,K.3642,D.177,F.108). Sanders, 24 Ekim'de Mustafa Kemal Paşa'ya yazdığı telgrafta orduların geri çekilme harekatında aksaklıklar görüldüğünü bazı hallerde düşmanın nitelik ve niceliğine bakılmaksızın 'Ingilizler geliyor' haberinin bile geri çekilme ile sonuçlandığını belirterek VII.Ordu'nun Halep ve çevresini kendisinden daha zayıf bir düşman karşısında savaşmaksızın terk etmeyeceğini ümit ediyorum demiştir (ATASE,A.4/10481,K.3642,D.177,F.125).

Mustafa Kemal Paşa; "Memleketin bir karış topră̆ını sebepsiz yere terk etmemeyi ordular grubunun namus görevi telakki ederim" diyerek VII. Ordu'nun Halebin güneyi ile Katma arasinda mevzileneceğini ancak düşman taarruzu başarılı olursa geri çekileceğini ifade ederek düşmanın İskenderun Körfezine asker çıkarması halinde de geri çekilmek zorunda kalacağını belirtmiştir (ATASE,4/11122,K.3705,D.29,F.8-1).

Halep'in güneyindeki çatışmalar 25 Ekimde başlamıştır. Araplar öğleden sonra 1. Tümen mevzilerine saldırmışlarsa da geri püskürtülmüşlerdir. Akşama doğru 1500 Arap süvari doğudan şehre girip Kale ile Hükümet Konağını ele geçirdilerse de Türk askerleri tarafından sokak çatışmalarıyla şehirden çıkarılmışlardır. Mustafa Kemal Paşa bu çarpışmayı şu şekilde anlatmıştır: "Ben Halep’te tam deyimi ile bir sokak savaşı yaptım. Saldıranlar, tamamen yenilmiş ve bozguna uğramış olarak atıldılar ve kovalandılar”. Halep ahalisi de silahlanarak Türklere karşı çarpışmışlardır. Sokak savaşında Türk askerlerinin işini zorlaştıran en büyük tehlike hemen hemen her çatıdan üzerlerine yağan mermi ve el bombası ve kadınlar tarafından dökülen kızgın yağ sağanağı olmuştur. Mustafa Kemal Paşa, artan saldırılar karşısında akşama doğru karargâhı'nı şehrin dışında ve istasyonun $2 \mathrm{~km}$. kadar kuzeyinde bulunan bir tepeye aldı ve şehri boşalttı. Ali Fuat Paşa'nın komutası altında bulunan ve Arap asiler tarafından sürekli taciz edilen 20. Kolordu'ya bağlı 1. ve 11. Tümenler, Halep İstasyonunun bir 
kısmını havaya uçurup, 25 Ekim sabahı Halep'in 8 kilometre kuzeyindeki tepelerde mevzilenmiştir. Saat 10.45 'te İngilizler dört süvari alayı, zırhlı otomobiller piyadeler ve Arapların katıldığ 1 bir saldırı yapmışlarsa da 1. Türk Tümeni bu saldırıyı püskürtmüştür (Sanders,1999:109). Ancak devam eden çatışmalarda İngilizler saldırılarını arttırınca Mustafa Kemal Paşa "Ordunun maksadı memleketin bir karış toprağını sebepsiz yere terk etmemek olmakla beraber düşmanın faik kuvvetlerle ciddi teşebbüsatı karşısında orduyu müdafaa-yı katiyye için muvafik maksatla toplamaktır. Bu nokta-i nazardan ordunun istikameti asliyesi Katma-İslahiye'dir" (ATASE,4/11122,K.3707,D.34, F.23-1) diyerek Halep'ten Katma istikametine doğru geri çekilme kararı almıştır (ATASE, 4/10481,K.3642,D.177,F.125). Bu karar neticesinde VII. Ordu kolay savunma yapabilmek amacıyla Haleb'i boşaltarak kuzeyindeki dağlık arazide mevzilenmiştir. Böylece düşmanın zırhlı otomobillerinin ve süvarilerin etkinliklerini en aza indirmek amaçlanmıştır. Yoğun İngiliz hava saldırısı sebebi ile Halep tahliye edilinceye kadar istasyonda bulunan iki hava savunma topu son trenin hareketine kadar sabit kaldı. Toplar tren hareket ettikten sonra 205 numaralı otomobil kolu ile Katma' ya nakledildi (ATASE, 4/11132,K.3707,D.29,F.70-1). 27 Ekim'de Halep İngilizler tarafından işgal edildi. 27 Ekim'de İskenderun limanına 74 numaralı Alman denizaltısı gelerek Tarsus sahili, Kıbrıs civarında herhangi bir hareketlilik olmadığını rapor etmiştir (ATASE, 4/10481, K.3642, D.177, F.130). İskenderun sahilini korumakla görevli 41. Tümen 3. Kolordu emrine verilmiş böylece İskenderun Körfezini koruma görevi de VII. Ordu'nun uhdesine girmiştir (ATASE,4/11122, K.3707, D.34, F.23-1). Mustafa Kemal Paşa 28 Ekim 1918'de Katma'dan kumandasındaki birliklere şu emirleri vermiştir:

“Düşman bugün 20. Kolordu Cephesi'nde ciddi faaliyet göstermemiştir. 3. Kolordu mintıkasında bulunan Antakya'da Hükümet-i Arabiye ilan edildiği işitilmiştir. Bu hadisenin Halebin batısındaki Haram ve Reyhanlı kasabalarına sürat-i sirayeti memuldür. VII. Ordu İskenderun şehri ve sevahiliyle beraber (İskenderun, Belen Geçidi, Afrin, Cebel-i Semaan'ın şimal kısmı üzerinden Zirkat, Deyr Cemal, Tel Ruf'at, Defterdar, Halep) hattı umumiyesini muhafaza edecektir. Kolordular yanında hattı fasıl Afrin Vadisidir. 3. Kolordu Iskenderun sahil mintıkasında vazifesini ehemmiyetle ifa edebilmek için İskenderun-Büyükdere sahil yolunu ve Top Boğazl-Antakya civarında mümkün olduğunca güney istikamette kuvvetli müfrezelerle bulunmalıdır. 3. Kolordu Katma'da bulunan 24. Tümenini Afrin ve İskenderun çevresini korumak üzere Marta-Yaylit-BeytiyeImrad hattına yerleştirecektir. Kolordu Hamam grubu da bir müfreze ile Reyhaniye istikametini muhafaza edecektir. 20. Kolordu Cerablus-Ziyaret arasinda 43. Tümeni bulundurarak Kilis istikametini emniyet altına alacaktır. İki kıtası ise Deyr-i Cemal ve Tel Rlf'at-Defterdar hattında bulunacaktır. 3. ve 20. Kolordular Cebel-i Seman ve Zarikat civarında bulundurulacakları müfrezeleri ile irtibatlarını koparmayacaklardır. Ordu karargâhı Katmadadır" (ATASE, 4/10481, K.3642,D.177,F.139).

İhtiyat kuvveti olarak bir hücum taburu ile kuvvetli bir makineli tüfek birliğini trenle Katma'ya VII. Orduya gönderilmiştir (Sanders,1999: 109). İngiliz ve Arap birlikleri Katma hattını geçmek için saldırmışlarsa da püskürtülmüşlerdir. Böylece 500 km'lik İngiliz ilerlemesi durdurulmuş ve bir savunma hattı oluşturulmuştur (Nedim, 1995: 159).

Mustafa Kemal Paşa 28 Ekim'de Raco’ya gelerek 44.Tümeni teftiş etmiştir (ATASE, 4/10481, K.3642, D.177, F.139). VII. Ordu karargâhı'nın Racoya nakledilmesini emrederek yerine Ali Fuat Paşa'yı vekaleten ordu komutanı atayan Mustafa Kemal Paşa, öğle vakti Adana'ya hareket etmiştir (ATASE,4/11122,K.3707,D.177, F.93).

30 Ekim 1918'de Mondros Mütarekesi'nin imzalanmasıyla Liman Von Sanders, Yıldırım Ordular Grup Komutanlığ görevini 31 Ekim'de Mustafa Kemal Paşa'ya devretti. Bağdat'in İngilizler'den geri alınması için kurulan Yıldırım Orduları ateşkes sonrasında şu noktalarda bulunmaktaydı: Yıldırım Ordular Grubu karargâhı, II. Ordu karargâhı ve 12. Kolordu karargâhı Adana'da, 23. Fırka karargâhı Tarsus'ta, 15. Kolordu karargâhı ve 44. Tümen karargâhı Ceyhan'da, 41. Tümen karargâhı İskenderun'da, VII. Ordu karargâhı Raco'da 20. Kolordu karargâhı Katma'da, kolordu TettipTatmaraş-Aynıdakne'de, ihtiyat kuvveti Dercemal'de, 3. Kolordu karargâhı Kurtkulak İstasyonuKışla arasında, 24. Tümen karargâhı Kefrşil, tümen ise Maratah-Bablıyet-Halepli ve doğusunda, 
Mürettep Süvari Alayı Cebrin'de, 43. Tümen karargâhı Kelcebrin'de tümen Cebrin'in güneyinde, ihtiyat kuvveti de Ziyaret'te, 11. Tümen karargâhı Şuvarga'da, 1. Tümen ve karargâhı Kefrhaş'da (“Harp Tarihi,1959: 695").

Savaşın son günü Türk-İngiliz mücadelesi şu şekilde olmuştur: Halep-Katma yolu üzerinden gelen beş zırhlı İngiliz otomobili geri püskürtülmüş, İngiliz uçakları 20. Kolordu cephesi üzerinde uçarak Katma'dan batıya doğru hareket eden tren üzerine saldırarak bir Türk askerini şehit etmişlerdir. Antakya'da 400 kadar Arabın silahlandığı, üç İngiliz gemisinin Arsuz açıklarından Mersin'e yöneldiği tespit edilmişti. Liman Von Sanders'in ifadesi ile "Türk ordusu, bu son günlerdeki savaşlarda silahının şan ve şerefini korumayı başarmıştı" (Sanders, 1999:109). Mustafa Kemal Paşa, henüz 7 Ekim'de Halep savunmasını yaparken olacakları önceden görerek, aslında yapılacak bir şey kalmadığını ve Osmanlı Devleti'nin barış yapmaktan başka çaresi olmadığını ve savaşı neden kaybettiklerini şu şekilde izah etmiştir:

\begin{abstract}
"Düşmanın malûm fâikiyeti karşısında ve bizim ordu namı altında tutulan beşer, altışar bin neferimizin ric'ati tabii idi. Fakat bu ric'at daima bir şekil muhafaza edilerek icra edilebiliyordu: Enver Paşa gibi bir ahmak müdir-i harekât-ı umumiye olmasa idi ve burada beş-on bin kişilik bir hey'et-i askeriyenin başında ilk top sadâsında ordusunu bırakıp kaçan ve şahsını kurtarmak için şaşkın tavuk gibi öteye, beriye iltica eden kumandan bulunmasa idi, hiçbir vaziyet-i askeriyeyi takdir edemeyen bir Dördüncü Ordu Kumandanı bulunmasa idi ve bunların başında muharebenin ilk gününden itibaren hiçbir tesir ve nüfuzu kalmayan bir grup karargâhı olmasa idi. Bu andan sonra, artık sulhten başka yapılacak bir şey kalmamıştır” (Karakaş, 2018:505).
\end{abstract}

\title{
Sonuç:
}

I.Dünya Savaşı içerisinde Türk orduları'nın en zor durumda kaldıkları cephelerin başında güney cepheleri yani Irak, Sina-Filistin Cepheleri gelmektedir. Bu cephelerde Türk orduları Alman Genel Kurmayının hedefleri doğrultusunda yönlendirilmiş ve Mustafa Kemal Atatürk'ün Büyük Nutku'nda gayet sarih bir şekilde ifade ettiği gibi Türk orduları zayıf düşürülmüştür. Enver Paşa özellikle güneyde İngiliz, doğuda Rus tehlikesi açıç̧a ortada iken Türk ordularının en güzide tümenlerini Bulgar ve Avusturya ordularına destek olarak göndermesi Türk ordusunda görev yapan Liman von Sanders gibi Alman komutanlar tarafından bile büyük bir fedakarlık olarak değerlendirilmiştir.

Genel kanı savaşların sonuçlarını muharip sınıfların cephelerde göstermiş oldukları maharetin belirlediği şeklindedir. Bu bir gerçek olmakla birlikte tek başına yeterli değildir. Cephede savaşan unsurların lojistik destek ve sağlık hizmetleri cephe hattında savaşabilecek sağlıklı ve güçlü askerler olmasını sağlar. Bu açıdan güney cephesi'nde Türk ordusunun karşında bulunan İngiliz ordusu, askerlerinin her türlü ihtiyacını rahatça karşılamakta ve herhangi bir eksiklik durumunda yerine yenisini ve ihtiyaç olduğu anda koyma kabiliyetine sahip bulunmaktadır. İngilizler çöle döşemiş oldukları demiryolu ve dekovil hatları ile veyahut Akdeniz'de serbestçe dolaşan savaş ve kargo gemileri ile ihtiyaçlarını karşılamakta, askerlerini istedikleri yere nakledebilmektedirler. Türk ordusu demiryolu imkanına sahip olsa da oldukça kısıtlıdır. Özellikle Toros Tünelleri ancak 1918 Eylül ayında devreye girdiğinden cephane ve personel takviyesi İstanbul yolu ile yapılan Türkler açısından güney cephesi’ndeki savaşların sonucunu etkileyebilecek kolaylık sağlayamamıştır.

İngiliz ordusu 1918 yılında Irak Cephesi'nden dahi asker kaydırarak Sina-Filistin Cephe hattını güçlendirmeye gayret ederken, Türk ordusu Sina-Filistin Cephesini güçlendirmek yerine buradaki subayların bir kısmını dahi alarak Kafkas İslam Ordusunu kurmuş, Bakü üzerine harekata geçmiştir. Elbette ki Azerbaycan Türklerinin Ermeni işgalinden kurtarılması önemlidir. Ancak Türk ordusu 15 Eylül'de Bakü'ye girerken 30 Ekim'de Şam, 27 Ekim'de ise Halep İngiliz işgaline uğramış, İngilizler Anadolu kapılarına dayanmıştır. Sina-Filistin Cephesi bozgunu gerçekleşmemiş ve IV.ve VIII. Türk orduları dağılıp, VII. Ordu zayıflamamış olsa idi Mondros Mütarekesi gibi ağır şartlar içeren bir ateşkes antlaşması ile karşı karşıya kalmayabilirdik. 
Yenilgi bu denli büyük olunca elbette ki Sina-Filistin Cephesi ve burada cereyan eden olaylar büyük tartışmalara gebe olmaya devam etmektedir. Haddizatında tartışmalar savaş stratejileri, savaşan tarafların güç dengeleri gibi konular üzerinden yapılmak yerine doğrudan doğruya Mustafa Kemal Paşa ismi üzerinden yürütülmektedir. Mustafa Kemal Paşa, VII. Ordu Komutanı olarak görev yaptığı bu savaşta İngilizlerin VII. Ordu'yu esir etmelerine engel olmuş, elinde kalan kuvvetlerini meşakkatli mücadeleler ile korumaya gayret etmiştir. Savaşta İngiliz ve Türk orduları arasındaki maddi güç dengesi tartışılamaz şekilde İngilizler lehinedir. Havada, karada ve denizde istedikleri harekatı icra edebilme ve kayıplarını telafi etme imkanları vardır. Bütün bu imkanlardan yoksun, komutası Almanların elinde bulunan ve özellikle de asker sayısı bakımından İngilizler'den çok az olan Türk ordusu elinden gelen gayreti göstermiştir. Mustafa Kemal Paşa, Türk tarihi için yalnızca Türk Millî Mücadelesine önderlik etmiş bir asker ve siyaset adamı değildir. Mustafa Kemal Paşa bir sancaktır. Sancak Türk yurdunu ve Türk Cumhuriyeti'ni iç ve dış tehditlere karsı koruma ve kollama vazifesi taşıyanların sembolüdür. Türk milleti ve Türklük kavramı ile mücadele içerisinde olanların ilk hedeflerinden biri bu sancağı indirebilmektir. Mustafa Kemal Paşa ismi Türk milletinde hürriyet, bağımsızlık, Türk milliyetçiliği, vatan sevgisi kavramlarının içini dolduran bir timsal olduğundan bu kavramın alacağı her zarar ve itibar kaybı düşman cephesi'nin kazandığı bir siper-ön karakol vazifesi görecektir.

Mustafa Kemal Paşa'nın Türk Milliyetçiliği üzerine inşa ettiği laik ve üniter Türkiye Cumhuriyeti Devleti, yeni düzeni benimsemek istemeyenler tarafından benimsenmek istenilmemiş, bu yüzden de kendi düşünceleri doğrultusunda gerçekliğe aykırı bir sözde tarih yaratmaya çalışmışlardır. Özellikle bu cephede Arap-İngiliz işbirliği bu zümre için göz ardı edilmesi ve üzerinin örtülmesi gereken bir gerçeklik olarak ortada durduğundan, hem bunun üzerini kapatabilmek hem de Mustafa Kemal Paşa'yı itibarsızlaştırma hevesi ile bu yenilginin faturasını siyasi hasım olarak gördükleri Mustafa Kemal Paşa'nın üzerine yıkmak istemişlerdir. Bu noktadan hareketle Sina-Filistin Cephesi'ndeki yenilgi Mustafa Kemal Paşa'ya bağlanarak hem Türk Milliyetçiliğine alternatif olarak gördükleri siyasi ümmetçilik fikri zedelenmeyecek, kendileri gibi düşünen gruplar oluşturulan bu sahte gerçeklikle motive ve konsolide edilecek hem de Mustafa Kemal Atatürk adının temsil ettiği değerler zedelenerek, içerisine sızabilecekleri ortam oluşturulabilecekti. Sina Filistin Cephesi ve bu cephede çarpışan Mustafa Kemal Paşa ve askerleri hakkındaki tarihi gerçekliğe zıt iddialar bilinmeyenleri ortaya çıkarmak endişesinden ziyade bilinenleri kendi penceresinden anlatabilme gayretidir. Örneğin, Suriye-Filistin Cephesi'nde IV.Ordu'da görev yapan C. Rifat Atilhan tarafından kaleme alınan Filistin-Suriye Cephesi'nde Kahramanlar ve Hainler adlı kitapta cephedeki mağlubiyet Mustafa Kemal Paşa'ya bağlanılmaya çalışılmaktadır. Oysa ki yazar, 1918 yılında Tasvir-i Efkar gazetesinde "Suriye Hezimet-i Faciası ve Sebepleri" "Filistin Sahne-i Hezimeti" başlıkları altında yazı dizisi olarak kaleme aldığı hatıralarında gerek Mustafa Kemal Paşa'dan gerekse de Albay İsmet Bey'den övgü ile bahsetmektedir.

Tarihi olaylar belirli bir zaman dilimine göre değişiklik arz etmezler, oldukları andaki gibi kalırlar. Değişen onu kaleme alanların içerisinde bulundukları sosyo-ekonomik ve politik ortamlardır. Günlük siyasi hedefler için Türk Milletinin şanlı tarihi ile oynamak, kahramanlar ve hainler icat etmek, cephede düşmanların yapamadığını içten yapmak ve Mustafa Kemal Paşa'nın şahsında Türk tarihi ile hesaplaşmak manasına gelmektedir. Mustafa Kemal Paşa'yı ve eserini kötülemek bu gruplar için adeta bir varlik sebebidir.

\section{KAYNAKÇA}

\section{Telif-Tetkik Eserler:}

Balc1, M. (2019). İngiliz General Allenby'nin Filistin ve Suriye'deki Faaliyetleri, MUTAD, VI (1): 63-77.

Bayur, Y.H.(1991). Türk İnkılâbı Tarihi, C.III, K.III, Türk Tarih Kurumu Yayınları, Ankara 
Bayur,Y.H. (1956). Mustafa Kemal'in Falkenhaynla Çatışmasıyla İlgili Henüz Yayınlanmamış Bir Raporu, Belleten, Cilt:XX, Say1:80: 619-632.

Bayur, Y.H. (1990). Atatürk'ün Hayatı ve Eserleri, Atatürk Dil Tarih Yüksek Kurumu, Ankara.

Cemal, K. (2013). Nablus Meydan Muharebesi’nde Mustafa Kemal, Ankara Üniversitesi Türk Inkllap Tarihi Enstitüsü Atatürk Yolu Dergisi, S.51: 617-651.

Çeliker,H.F.(1988). Atatürk'ün Yaşamından Falkenhayn Mustafa Kemal Anlaşmazlığı, Atatürk Araştırmaları Merkezi Dergisi, C.V, S.13: 167-182.

Çulcu, M.(1993). Erkân-ı Harb Binbaşı Vecihi Bey'in Anıları: Filistin Ricatı, Arba Basım, İstanbul.

Çulcu, M. (2009). Arşivi Kaybolan Savaş, Kaştaş Yayınevi, İstanbul.

Emir, H.H. (2002). Yıldırım, Genelkurmay Basımevi, Ankara.

Erickson, J. (2009). Dünya Savaşında Osmanlı Ordusu, Türkiye İş Bankası Yayınları, İstanbul

Guhr, H.(2016). Anadolu'dan Filistin'e Türklerle Omuz Omuza, Türkiye İş Bankası Yayınları,

Hatipoğlu, S.(2009). Filistin Cephesinden Adana ya, Yeditepe Yayınları, İstanbul.

Harp Tarihi Vesikaları Dergisi, (1959). S.27,Vesika No: 695.

Karakaş, N. (2018). Nablus Muharebesi’nde Mustafa Kemal Paşa: İthamlar ve Gerçekler, Tarih İncelemeleri Dergisi, XXXIII/2, s.481-519.

Kocahanoğlu, O.S. (2005). Ali Fuat Cebesoy'un Arşivinden Askeri ve Siyasi Belgeler, Temel Yayınları, İstanbul.

Lord, K. (2003). Atataürk, Bir milletin Yeniden Doğuşu, Altın Kitap, İstanbul.

Mirliva Sedat, (2009). Filistin'e Veda, Yeditepe Yayınları, İstanbul.

Nedim, Ş.M. (1995). Filistin Savaşı(1914-1918), Genelkurmay Basımevi, Ankara.

Osmanlı Belgelerinde Birinci Dünya Harbi (2013), Devlet Arşivleri Genel Müdürlüğü, İstanbul

Pomianowiski, J. (1990), Osmanlı Imparatorluğu'nun Çöküşü, Kayıhan Yayınları, İstanbul

Renouvin, P.(1982). Birinci Dünya Savaşı ve Türkiye, Altın Kitaplar,

Selek, S. (2006). İsmet İn̈nü Hatıralar,C.1, Bilgi Yayınevi, Ankara

Sanders, L.,(1999). Türkiye'de Beş Yıl, C.III, Yeni Gün Yayınları, Ankara

Tezer, S. (2009). Filistin Cephesinden Adana'ya, Yeditepe Yayınları, İstanbul

Turan, M. (2015). I. Dünya Savaşı Öncesinde Avrupa Devletleri’nin Siyaset Stratejileri ve Osmanlı Devleti”, 100. Yılında I.Dünya Savaşı Uluslararası Sempozyumu, Ankara.

Yıldırım, M. (2009), 58 Gün/Mustafa Kemal ile Filistin'den Anayurdun Dağlarına, Ulus Dağ1 Yayınlar1, Ankara.

Y1lmaz, F.(2003). General Allenby’nin Hatıratı, Berikan Yayınevi, Ankara

Wallach,J. L. (1985). Bir Askeri Yardımın Anatomisi, Türkiye'de Prusya-Almanya Askerî Heyetleri 1835-1919, ATASE Yayınları Ankara. 


\section{Arşiv Belgeleri:}

\section{Genelkurmay Askeri Tarih ve Stratejik Etüt Başkanlığı Arşivi}

ATASE ATA ZB 45 12aa

ATASE ATA ZB 35 91ab

ATASE ATA ZB 35 91ac

ATASE ATA ZB 45 91ad

ATASE ATA ZB 35-91

ATASE, ATA ZB 3591 aa

ATASE, ATA ZB 35 91ae

ATASE, ATA ZB $3591 \mathrm{ag}$

ATASE, ATA ZB 4512

ATASE, ATA ZB 45 12bk

ATASE, ATA ZB 45 12bh

ATASE, ATA ZB 45 12bi

ATASE ATA ZB 45 12at

ATASE, ATA ZB 45 12bg

ATASE ATA ZB 45 12bd

ATASE, ATA ZB 45 12bc

ATASE, ATA ZB 45 12av

ATASE ATA ZB 45 12be

ATASE, ATA ZB 45 12bj

ATASE ATA ZB 45 12bm

ATASE, ATA ZB 45 12bn

ATASE ATA ZB 45 12bl

ATASE ATA ZB 45 12bf

ATASE ATA ZB 35 91afa

ATASE 1/1 K.222, D.342, F.7.

ATASE K.3718, D.38, F.1-24.

ATASE 4/11122, K.3705, D.28, F.5-3

ATASE 4/11122, K.3705, D.34, F.8-2a

ATASE 4/11122, K.3705, D.28, F.7-1

ATASE 4/11122, K.3705, D.28, F.13

ATASE 4/11399, K.3787, D.37, F.1-14

ATASE 1/1, K.222, D.342,F.7-2.

ATASE 5/7815, K.4523, D.19, F.1-40
ATASE /1, K.222, D.342.F.7-20

ATASE A/1, K.222, D.342, F.7-17

ATASE A/1 K.222, D.342, F.7-14

ATASE A1/1, K.222, D.342,F.7-16

ATASE 4/7302, K.3220, D.62, F.8

ATASE 4/11122, K.3705, D.28, F.7-6

ATASE 4/11122, K.3705, D.28, F.18-2a

ATASE, 4/11122, K.3705, D.28. F.18-4

ATASE, A/4,11122, K.3707, D.35, F.13

ATASE 4/11122, K.3705, D.28, F.20.

ATASE, A.1-1, K.222, D.342, F.7-117

ATASE, A.1-1, K.222, D.342, F.1-118.

ATASE, 4/11122, K.3705, D.28,F.20-1

ATASE, A.1-1, K.222, D.342, F.7-123

ATASE, 4/11122, K.3707, D.35, F.17.

ATASE, 4/11122, K.3705, D.28, F.22

ATASE, A4/10481, K.3642, D.177, F4

ATASE,A4/11122, K.3705, D.29, F.32-4

ATASE, 4/1993, K.2697,D.113, F.38-5

ATASE, 4/11122, K.3705, D.28, F.25-8

ATASE, A4/11122, K.3707, D.42, F.4

ATASE 4/11122,K.3705, D.29, F.29

ATASE, A4/11122, K.3705, D.28, F.44

ATASE, 4/11122, K.3705, D.29, F.8-1

ATASE, 4/11122, K.3705,D.29, F.13-1

ATASE, 4/11122, K.3705, D.29, F.13-2

ATASE, 4/11122, K.3705, D.29, F.31-4

ATASE,4/10481, K.3642, D.177, F.89.

ATASE,4/10481,K.3642,D.177 F.108

ATASE, 4/11132, K.3707, D.29, F.70-1

ATASE, 4/10481,K.3642, D.177, F.125.

ATASE, 4/10481, K.3642, D.177, F.130

ATASE,4/11122, K.3707, D.34, F.23-1

ATASE, 4/10481, K.3642, D.177, F.139

ATASE, 4/11122,K.3707,D.177, F.93 